\title{
Neogene stratigraphic architecture and tectonic evolution of Wanganui, King Country, and eastern Taranaki Basins, New Zealand
}

\author{
PETER J. J. KAMP 1 \\ ADAM J. VONK ${ }^{1}$ \\ KYLE J. BLAND ${ }^{1}$ \\ ROCHELLE J. HANSEN ${ }^{1}$ \\ AUSTIN J. W. HENDY ${ }^{1,2}$ \\ AVON P. MCINTYRE 1,3 \\ MELODIE NGATAI ${ }^{1}$ \\ STUART J. CARTWRIGHT ${ }^{1}$ \\ SHAUN HAYTON ${ }^{1,4}$ \\ CAMPBELL S. NELSON ${ }^{1}$ \\ ${ }^{1}$ Department of Earth Sciences \\ The University of Waikato \\ Private Bag 3105 \\ Hamilton 2001, New Zealand \\ ${ }^{2}$ Department of Geology \\ University of Cincinnati \\ Cincinnati, OH 45221-0013, USA \\ ${ }^{3}$ Geoscience Australia \\ GPO Box 378 \\ ACT 2601, Australia \\ ${ }^{4}$ CRL Energy Ltd \\ P.O. Box 29415 \\ Christchurch, New Zealand
}

\begin{abstract}
Analysis of the stratigraphic architecture of the fills of Wanganui, King Country, and eastern Taranaki Basins reveals the occurrence of five 2 nd order Late Paleocene and Neogene sequences of tectonic origin. The oldest is the late Eocene-Oligocene Te Kuiti Sequence, followed by the earlyearly Miocene (Otaian) Mahoenui Sequence, followed by the late-early Miocene (Altonian) Mokau Sequence, all three in King Country Basin. The fourth is the middle Miocene to early Pliocene Whangamomona Sequence, and the fifth is the middle Pliocene-Pleistocene Rangitikei Sequence, both represented in the three basins. Higher order sequences (4th, 5 th, 6th) with a eustatic origin occur particularly within the Whangamomona and Rangitikei Sequences, particularly those of 6th order with $41000 \mathrm{yr}$ periodicity.

The base of each 2 nd order sequence is marked by marine flooding and represents a discrete phase in basin development. The Te Kuiti Sequence accumulated in non-marine and shelf environments, whereas the Mahoenui Sequence accumulated
\end{abstract}

G03057; Online publication date 1 December 2004 Received 4 July 2003; accepted 30 January 2004 mostly at bathyal depths; no regressive deposits are evident, having been eroded during subsequent uplift. The Mokau Sequence comprises shoreface and non-marine deposits including coal measures. The Whangamomona Sequence accumulated during extensive flooding of King Country Basin and collapse of the eastern margin of Taranaki Basin. It has a thin retrogressive part (Otunui Formation) and a thick progradational component (Mount Messenger to Matemateaonga Formations). The latter component represents the northward progradation of a continental margin wedge through Wanganui and King Country Basins. The Rangitikei Sequence is marked by extensive flooding at its base (Tangahoe Mudstone) and reflects the pull-down of the main Wanganui Basin depocentre. This sequence comprises a second progradational margin wedge, which migrated on two fronts, one northward through Wanganui Basin into King Country Basin, and a second west of the Patea-Tongaporutu High, through the Toru Trough into the Central and Northern Grabens of Taranaki Basin and on to the Western Platform as the Giant Foresets Formation, thereby building up the modern shelf and slope.

All five sequences are erosionally truncated, with up to $2100 \mathrm{~m}$ of exhumation that affected much of central North Island. The Pliocene timing of the start of erosion, together with its pattern, point to long wavelength deformation of the crust driven from the upper mantle consequent upon migration of the late Miocene andesitic volcanic arc from northern Taranaki Basin into Taupo Volcanic Zone.

Keywords North Island; Wanganui Basin; King Country Basin; Taranaki Basin; Taranaki Fault; Pungapunga Formation; Whangamomona Group; Rangitikei Supergroup; sequence stratigraphy; tectonics; new structural names; new stratigraphic names

\section{INTRODUCTION}

The main objectives of this paper are to present and interpret the broad Neogene stratigraphic architecture of Wanganui, King Country, and eastern Taranaki Basins, to identify the orders of cyclicity within them, and to draw tectonic interpretations, particularly for eastern Taranaki Basin margin. In so doing, the paper also provides a geological context for more detailed investigations of particular formations appearing in this special issue and elsewhere (e.g., Vonk et al. 2002; Hansen \& Kamp 2004, this issue; Hendy \& Kamp 2004, this issue). We do not consider here the late Paleogene Te Kuiti Sequence in any detail as our ongoing work has identified up to 10 4th order sequences within it and we cannot do justice to their description and interpretation in the space available.

Sedimentary basins in western North Island include Wanganui Basin, King Country Basin (new name; formerly North Wanganui), and eastern parts of Taranaki Basin. While 
these are discrete depocentres, they nevertheless contain similar Neogene sedimentary successions, and much of their late Neogene geological history is in common. Analysis of the stratigraphic architecture of the fill of these basins reveals the occurrence of five 2 nd order sequences of tectonic origin. These include the late Eocene-Oligocene Te Kuiti Sequence (King Country Basin), the early-early Miocene (Otaian) Mahoenui Group/Sequence (King Country Basin), the late-early Miocene (Altonian) Mokau Group/Sequence (King Country Basin), the middle Miocene to early Pliocene Whangamomona Group/Sequence (new), and the middle Pliocene-Pleistocene Rangitikei Supergroup/Sequence (new) (both in all three basins). Higher order sequences are evident in the Te Kuiti Sequence (4th order), Whangamomona, and Rangitikei Sequences, with those of 5th (100 $000 \mathrm{yr})$ and 6th (41000 yr) order being especially common in the latter two sequences.

Several major findings emerge from synthesis of the stratigraphic architecture of these basins. (1) They contain two erosionally truncated shelf-slope-basin depositional systems that represent the northward progradation of two continental margin wedges, one of middle Miocene to early Pliocene age (Whangamomona Sequence), and another of middle PliocenePleistocene age (Rangitikei Sequence). (2) Aspects of the structural development of eastern Taranaki Basin, particularly the timing of movement on Taranaki and Manganui Faults and subsequent collapse of this margin, can be clarified from investigation of the stratigraphic record onshore. (3) Improved concepts of the paleogeographic development of the region and controls on source-to-sink sediment pathways are possible from analysis of the onshore record. (4) There has been a very significant Pliocene-Pleistocene tectonically driven uplift and erosion episode centred on the King Country Basin and extending out into Wanganui Basin and eastern parts of Taranaki Basin.

\section{GEOLOGICAL OUTLINE OF CENTRAL-WESTERN NORTH ISLAND}

A simplified geological map of central-western North Island is shown in Fig. 1. Figure 2 is a structure map of the same region. Figure 3 shows schematically the occurrence of major Neogene stratigraphic units in each of the three basins. The eastern margin of Taranaki Basin has traditionally been marked by the Taranaki Fault (e.g., King \& Thrasher 1996). Note, however, in Fig. 1 and 2 how the boundaries of the late Miocene and Pliocene stratigraphic units cross the projected trace of the Taranaki Fault. This highlights the common geological history the basins have had during the late Neogene.

The King Country Basin lies to the east of the northern part of Taranaki Basin (Fig. 2). Its southern and common boundary with Wanganui Basin is poorly defined with no obvious structure between them. It broadly lies within a southward-dipping monocline (Wanganui Monocline, Fig. 2) that reflects progressive southward onlap on to basement, which has been modified by later uplift and tilting to the south and southwest. For the purposes of defining the boundary between these basins, the base of the Matemateaonga Formation has been adopted. This marks the stratigraphic point at which substantial subsidence of basement in the northern part of Wanganui Basin started, with marked southward migration of the shoreline. The eastern margin of Wanganui Basin is marked by the axial ranges, and the western margin is marked by the offshore continuation of the Patea-Tongaporutu High and by the D'Urville High (Fig. 2).

\section{Outcrop patterns}

Much of the Neogene tectonic development of the region can be read from the geology and structure maps (Fig. 1,2). A striking feature of the outcrop pattern in the northern part of Wanganui Basin and the southern part of King Country Basin is the west-east strike of the formations (Fig. 1). This involves the Mount Messenger Formation through to Nukumaruan strata (late Pliocene to early Pleistocene) (Fig. 3). These units are structurally conformable and dip $2-4^{\circ} \mathrm{S}$ or SW. The strike of these beds is normal to the orientation of the plate boundary zone, and therefore the origin of the bedding attitude is not simply related to upper crustal shortening driven by plate convergence. Significantly, the distribution of Castlecliffian (middle-late Pleistocene; Fig. 1,3) strata only are influenced by the occurrence of the axial ranges (Tararua-Ruahine Range), suggesting that the uplift of these ranges occurred mainly during the Castlecliffian-Holocene interval.

In the central and northern parts of King Country Basin the stratigraphic units are Oligocene (Te Kuiti Group) and early Miocene (Mahoenui and Mokau Groups) in age and have shallow to negligible dip, being influenced more locally by tilting about the Herangi Range (Nelson et al. 1994), and faults (e.g., Ohura Fault) having northeast-southwest strikes sympathetic to those defining the Northern Graben in Taranaki Basin and the Taupo Volcanic Zone (Fig. 2).

In central and western parts of Taranaki Peninsula the Urenui Formation through to Tangahoe Mudstone successions are overlain by Mount Taranaki Quaternary volcanics and volcaniclastic sediments of the ring plain (Fig. 1). An issue is whether or not the marine formations maintain their character and west-east strike beneath the volcanic apron. This question impinges upon outcrop-subcrop correlations in Taranaki Peninsula and is addressed later in the paper.

\section{UPLIFT AND EROSION OF CENTRAL NORTH ISLAND}

The outcrop pattern of central-western North Island reflects long wavelength up-doming of central North Island and associated erosion of weakly lithified mudstone and associated lithologies. Figure 4 is a map showing the magnitude and pattern of erosion determined chiefly from analysis of the bulk density of mudstone cores. There are two sets of bulk density data underpinning the map, including a DSIR dataset obtained during the 1960s for regional gravity mapping (Reilly 1965) and made available by the Institute of Geological \& Nuclear Sciences Ltd, and a second dataset collected as part of this study, which concentrated on high density sampling in the main river valleys of Wanganui Basin (Fig. 4). The laboratory methods used for the determination of bulk density of core samples followed standard soil and rock mechanics methods (Franklin et al. 1979). Estimation of the amount of erosion for individual sites from the bulk density data was made by reference to a porosity-depth relationship determined by Armstrong et al. (1998) for calibration well sites in Taranaki Basin that are currently at maximum burial depths and have not experienced any uplift and erosion. The statistically fitted surface through the combined dataset also included 
Fig. 1 Simplified geological map of western North Island (modified from New Zealand Geological Survey 1972), showing the main stratigraphic units in the eastern Taranaki, King Country, and Wanganui Basins (see Fig. 2). Cross-section line $\mathrm{A}-\mathrm{A}^{\prime}$ is the basis for the chronostratigraphic panel in Fig. 11.

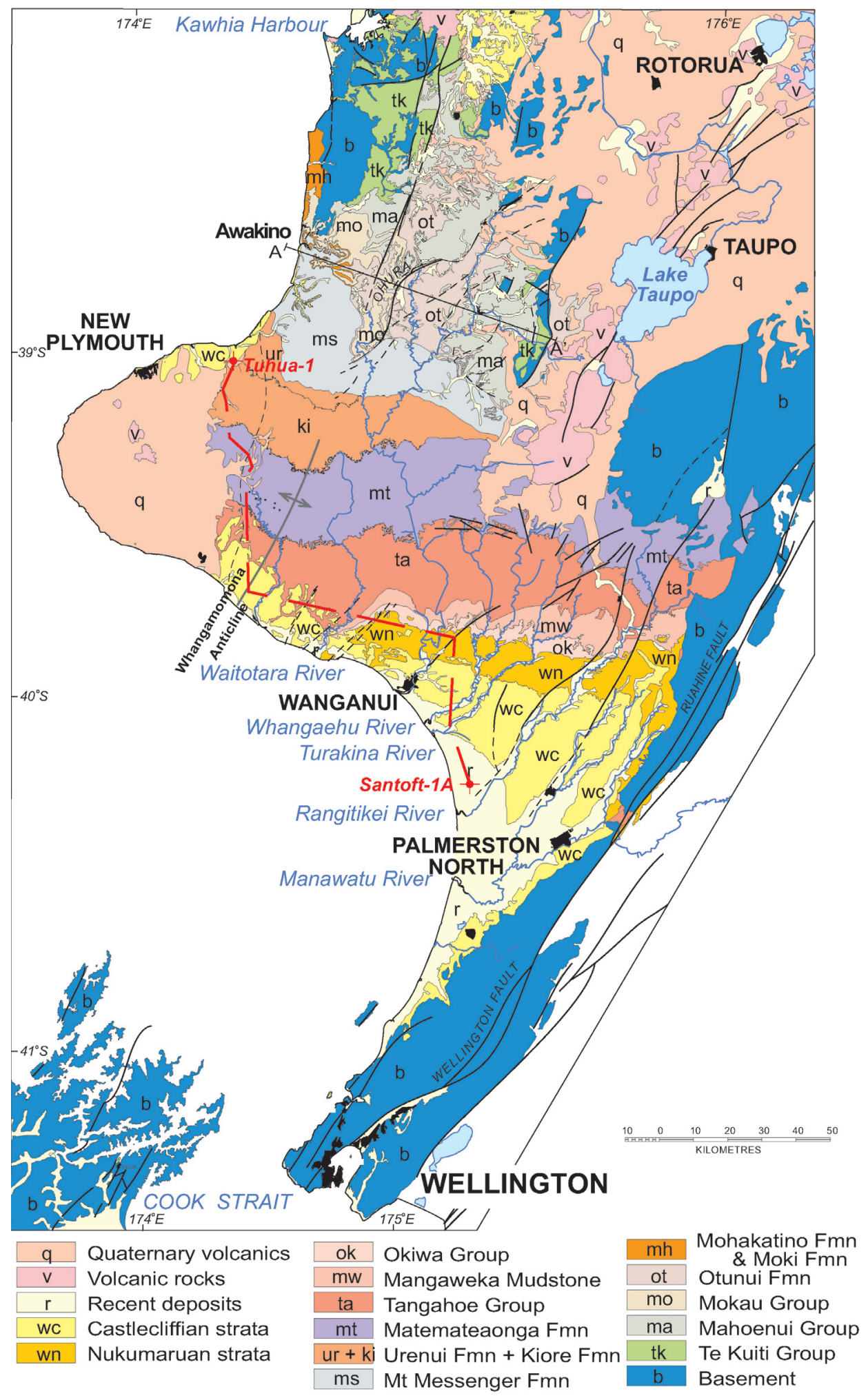

the erosion estimates made by Armstrong et al. (1998) for particular hydrocarbon well sites along the eastern margin of Taranaki Basin.

Figure 4 is essentially an erosion map as the data underpinning it reflect the amount of exhumation of the mudstone horizons sampled. The associated rock uplift is a more fundamental tectonic parameter and would be of larger magnitude, because the mean topography and any marine paleobathymetry that preceded the start of uplift need to be added to the amount of exhumation. The erosion map should, however, represent a reliable proxy for estimation of the magnitude of rock uplift because the mudstone cores were obtained in the valley bottoms, the mean topography over the King Country region is only c. $200-300 \mathrm{~m}$ above sea level, and the marine setting before the start of uplift was probably at shelf depth, as outlined below. 


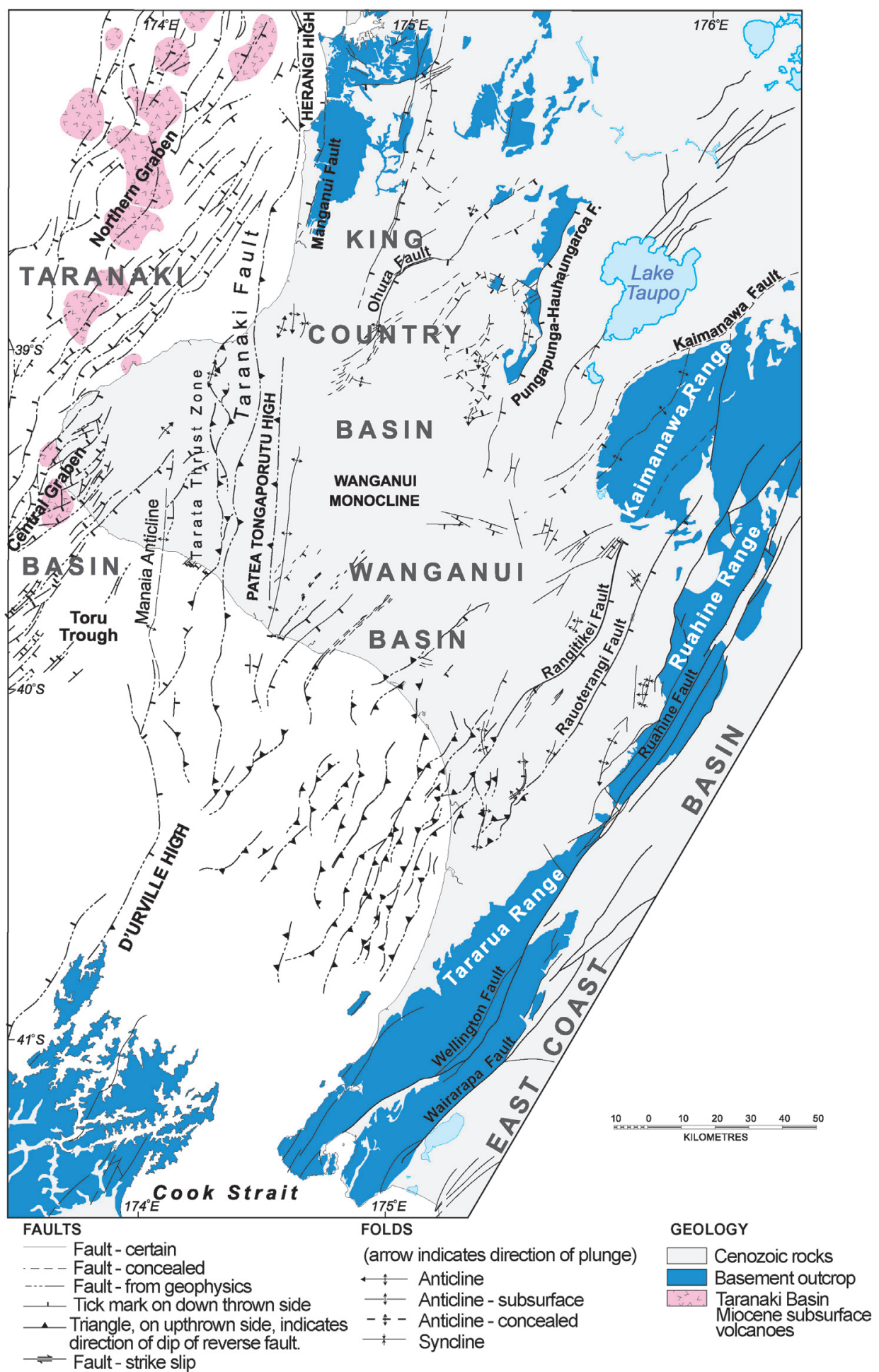

Fig. 2 Map of western North Island showing the major geological structures and the distribution of basement. While many of the structures are of Pliocene-Pleistocene age, some date back to the early Miocene and may not be currently active.
The magnitude of erosion varies systematically, increasing northward from Wanganui Basin into King Country Basin, and eastward from eastern Taranaki Basin into the King Country region (Fig. 4). The maximum amount of erosion is probably c. $2000 \mathrm{~m}$. Farther to the east in Hawke's Bay the $300 \mathrm{~m}$ spacing contour lines are inferred to swing to the north, thereby defining a subcircular northeast-southwest extended area of exhumation centred on or west of the Taupo Volcanic Zone: demonstration of this awaits the results of ongoing thermochronometric and exhumation studies. The zero erosion line offshore is presumed to have formed chiefly by wave planation and cliff retreat during successive Pleistocene marine transgressions and sea-level highstands, which also formed the uplifted flights of middle and late Pleistocene terraces in the vicinity of Taranaki Peninsula. Inland of the coastal zone, fluvial and slope processes acting on weakly lithified mudstone and sandstone are likely to have produced the erosion at rates that will have nearly approximated the rock uplift rates. In the Kaimanawa Range and northern Ruahine Range, the Neogene cover rock succession has been almost 


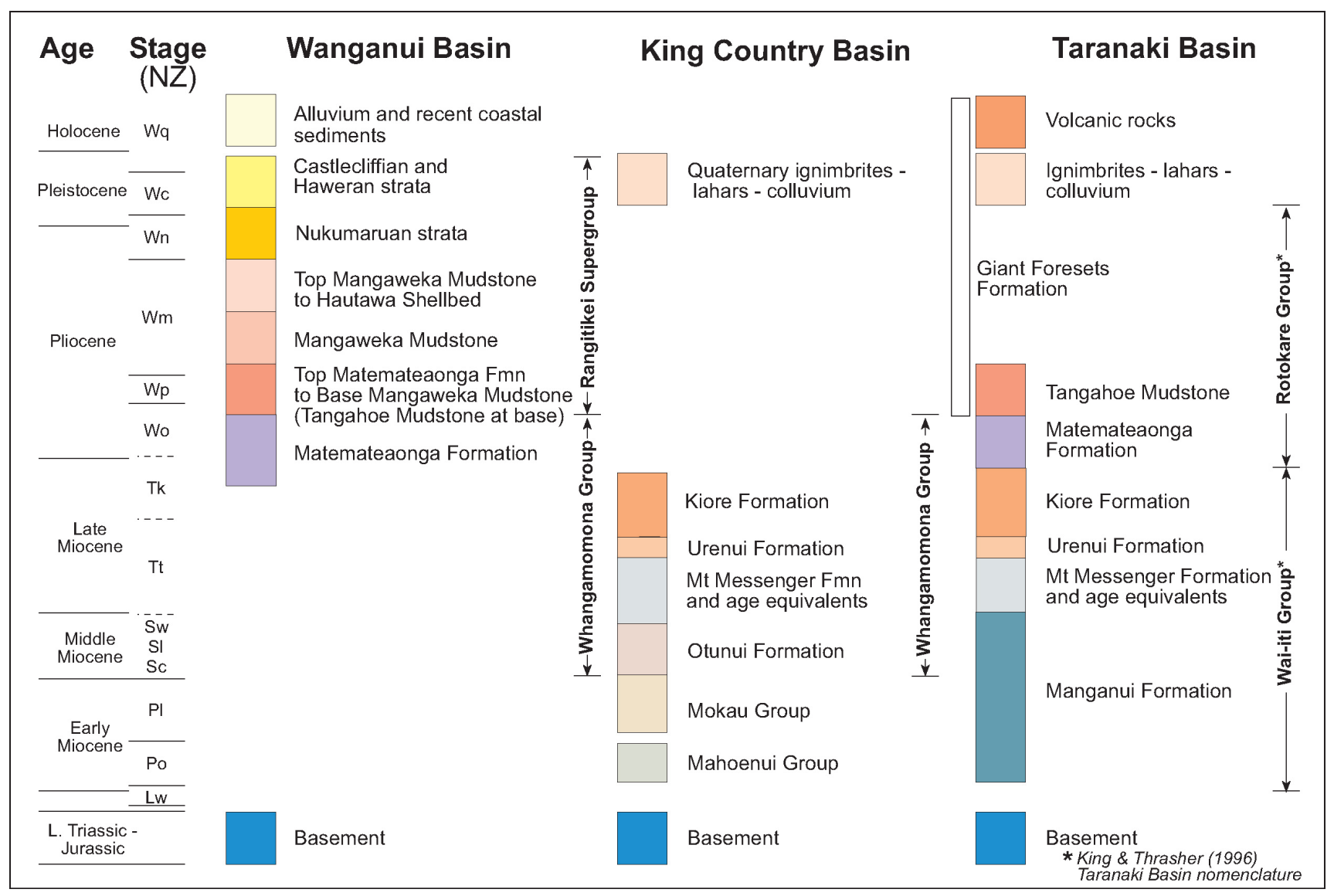

Fig. 3 The major Neogene stratigraphic units in each of Taranaki, King Country, and Wanganui Basins, and their age. The Moki and Mohakatino Formations, which occur within Manganui Formation in Taranaki Basin, are not shown.

completely removed and the exhumed basement surface, which is still evident in places, has been finely dissected (Fig. 4). The material eroded was dispersed to the surrounding basins, including northern Taranaki Basin (Giant Foresets Formation), Wanganui Basin (Rangitikei Supergroup), and Hawke's Bay Basin (Maungahururu Formation and Petane Group).

Two features about the erosion pattern that indicate it fundamentally originates from long wavelength up-doming of central North Island are the very close match between the orientation of the erosion contours (Fig. 4) and the strike of the major stratigraphic units (Fig. 1). Moreover, the coincidence of these geological signals with the contours of a positive isostatic anomaly on the regional gravity map (Reilly 1965), together with the long wavelength of the mild deformation of the surface expressed as rock uplift and erosion, point to the involvement of upper mantle processes in the origin of the uplift. Note on Fig. 4 how the uplift appears to be centred on or northwest of the Taupo Volcanic Zone, which is a Pleistocene volcanic arc. Its predecessor andesitic volcanic arc was located in northern Taranaki Basin until the latest Miocene, and during the Pliocene shifted southeastward, probably as a result of steepening of the dip of the subducted slab. Part of the broad doming and erosion of central North Island predated the outbreak of Taupo Volcanic Zone volcanism since late Pliocene andesite volcanoes (Puerora and Titiraupunga) rest on basement, requiring prior erosion of Miocene beds.

\section{Stratigraphic units removed}

The magnitude of erosion was substantial and leads to the question of what stratigraphic units were removed. We consider that these included mainly the Mokau and Mahoenui Groups and the middle Miocene through Pliocene stratigraphic units involved in the Wanganui Monocline. The former occurrence of these units as evidenced by the results of analyses of the bulk density of exhumed mudstone beds, indicates that the King Country Basin was a long-lived marine sedimentary depocentre, and points to its probable former depositional continuity with northern parts of Wanganui Basin, and possibly the East Coast Basin during the early Miocene. This has implications for understanding of the Neogene paleogeographic development of central North Island.

\section{STRATIGRAPHIC ARCHITECTURE OF THE BASIN FILLS}

To illustrate the stratigraphic architecture of the fills of the three basins in central-western North Island, a series of crosssections and related time-stratigraphic panels have been constructed. Figure 5 shows the lines of these cross-sections in relation to the distribution of the major stratigraphic units. The cross-sections (Fig. 6-9) are essentially well-to-well correlations keyed into outcrop. As many of the panels intersect basement, they also indicate the form of the structure 


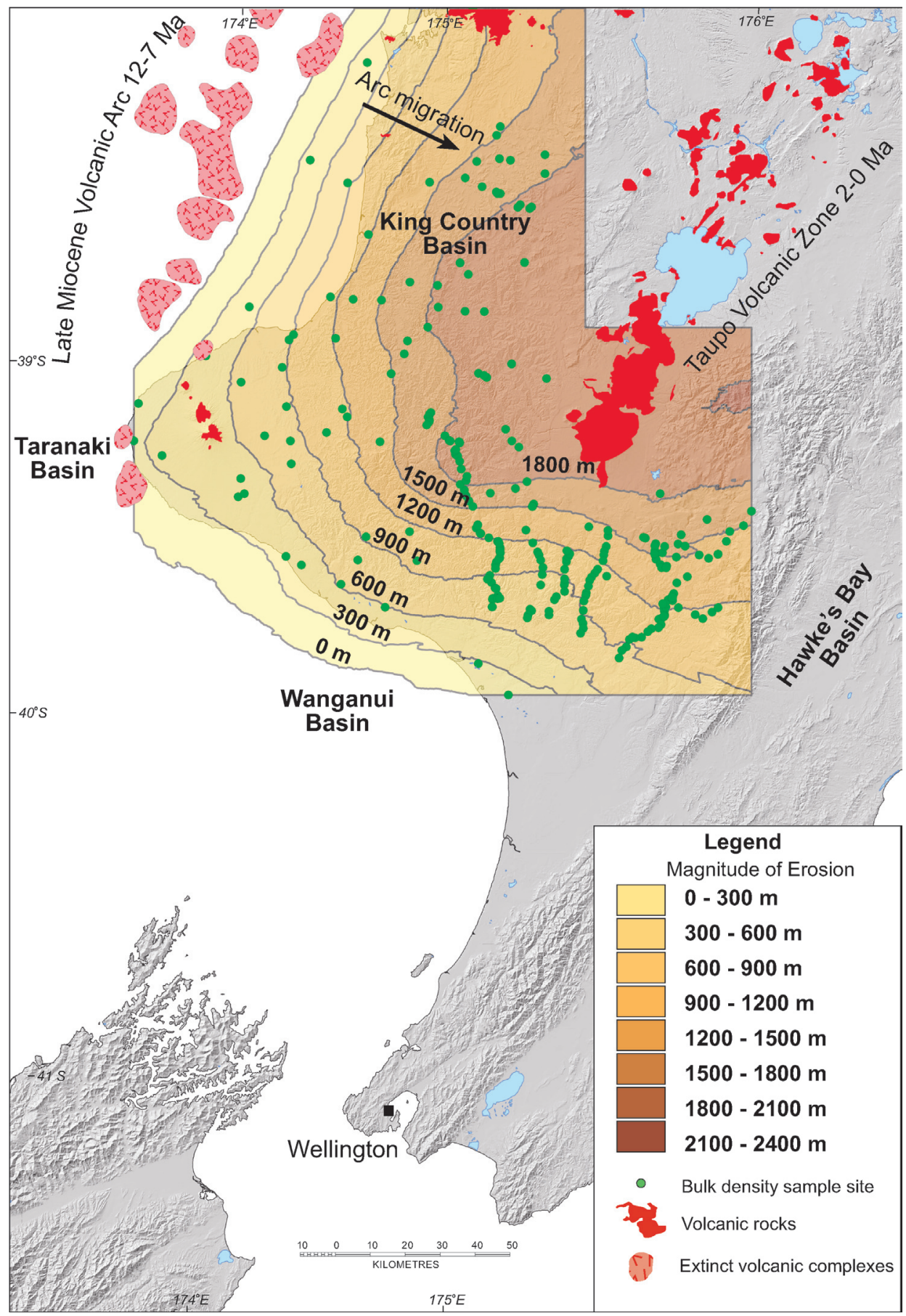

Fig. 4 Map showing the magnitude in $300 \mathrm{~m}$ contours and pattern of Pliocene-Pleistocene erosion over central North Island derived from mudstone bulk density data. See text for discussion.

contour on basement and hence the basin morphology. The identification of the stratigraphic extent of formations in the well sections has followed close analysis of their wireline $\log$ character.

\section{Wanganui Basin to King Country Basin: Parakino-1 to Ararimu-1 transect}

Figure 6 illustrates a cross-section through the axis of the Wanganui and King Country Basins. It shows the stratigraphic and structural concordance of the formations and how the slope on the basement surface is similar to the dip on the formation contacts. The Wanganui Monocline, defined from the dip of Neogene sediments (Fig. 2), is a reflection of the subsurface structure on basement. The cross-section also shows the persistent southward onlap of successive formations on to basement, suggestive of a north-facing paleoslope prior to later uplift and tilting to the south.

The time-stratigraphic section (Fig. 6) highlights particularly the occurrence of four major Neogene unconformity-bounded sequences (excluding the late Paleogene Te Kuiti Sequence). The first two are of early Miocene age. The Mahoenui Group comprises massive mudstone (Taumatamaire Formation) and flysch (Taumarunui Formation) facies (Hay 1967; Nelson \& Hume 1977; Topping 1978; Cartwright 2003). The initial subsidence of the basin containing this succession occurred during the Oligocene (Te Kuiti Sequence) and is marked in the south by thin (up to $30 \mathrm{~m}$ ), coaly, incised valley fill deposits, thin transgressive 
Fig. 5 Geological map of centralwestern North Island, including Taranaki Peninsula, showing the location of key hydrocarbon exploration holes and the line of four cross-sections illustrated in Fig. 6-9.

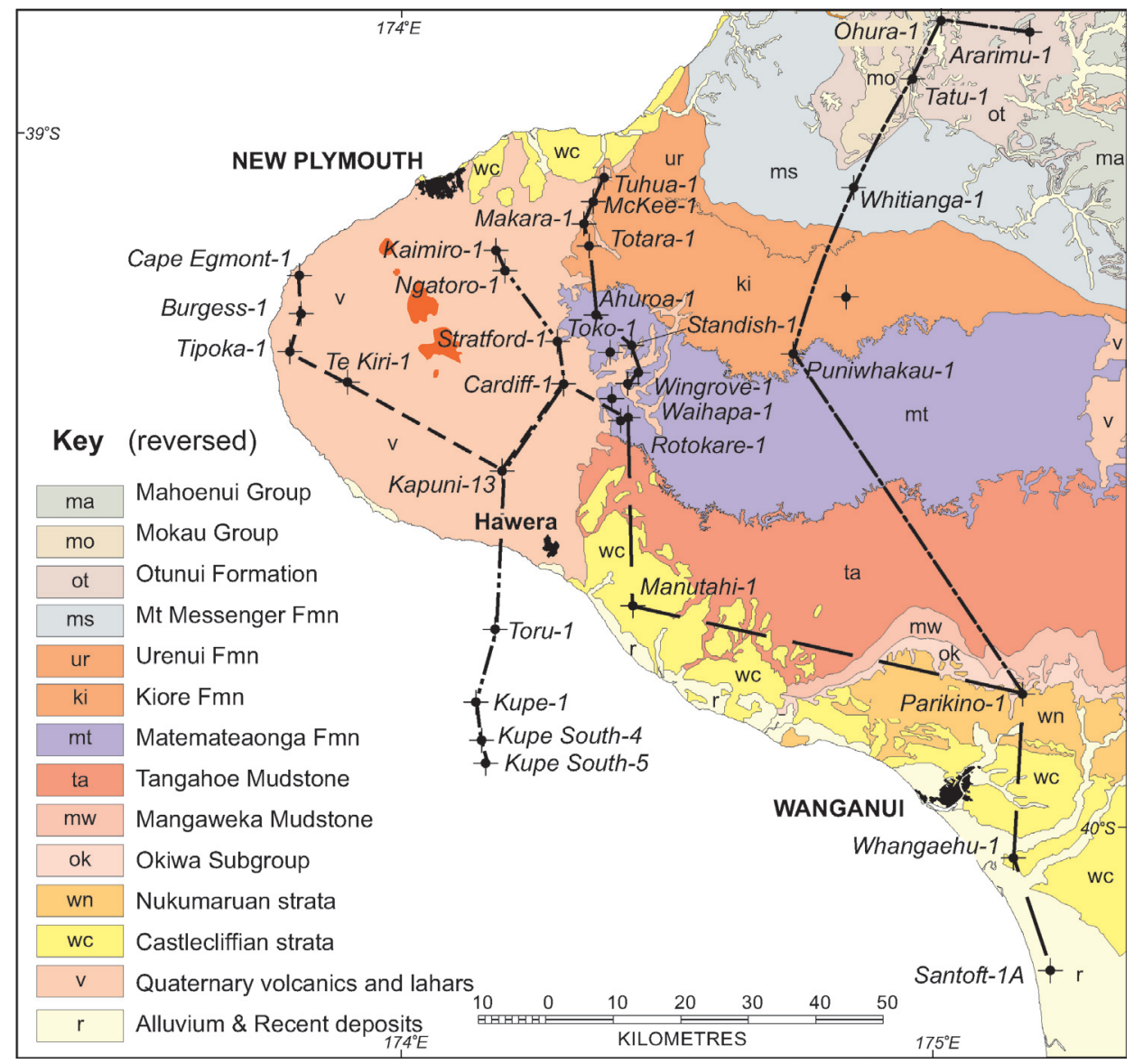

(onlap) shellbeds, and overlying marine neritic sandstone and mudstone beds (Pungapunga Formation (new) of the Te Kuiti Group (2nd order) sequence; Cartwright 2003). A glauconitic mudstone a few decimetres thick locally at the base of the Mahoenui Sequence marks a prominent flooding surface. It reflects initial terrigenous sediment starvation associated with rapid subsidence and flooding of the basin, marked onlap of basement around the margins, and the establishment of deep-water conditions. This was followed locally by the accumulation of c. $100 \mathrm{~m}$ of massive shelf mudstone and then by c. $1000 \mathrm{~m}$ of redeposited sediments (turbidites) that accumulated at bathyal depths. The Mahoenui Group is predominantly of Otaian age (Topping 1978). Surprisingly, no regressive slope or shelf facies have been identified at the top of the Mahoenui Group. Presumably, if they were originally present, they were abridged and eroded during a short-lived and marked phase of uplift and erosion that affected the whole of the Mahoenui depocentre.

This inversion of the basin was associated with reverse movement on the Ohura Fault. The upthrown block to the east of this fault partly sourced sediments to the area to the west of the Ohura Fault throughout the rest of the early Miocene (Altonian), where they formed the Mokau Group/ Sequence (Fig. 6). The Mokau Sequence comprises a lower transgressive sandstone (Bexley Sandstone), a coal measure, fluvial and intervening shoreface succession (Maryville Coal Measures), and an upper regressive shoreface sandstone (Tangarakau Sandstone). The upper surface of the sequence is conformable with the Otunui Fmn, and marks significant marine flooding.
The third Neogene megasequence is represented by the Whangamomona Group (Fig. 6, 7). During the middle Miocene the whole of the King Country region subsided. This resulted in the accumulation of a transgressive shelf succession represented by the (Clifdenian) LillburnianWaiauan age Otunui Formation (Mohakatino Formation of Hay 1967). It overlies the Mahoenui Group and minor Mokau Group east of the Ohura Fault, and Mokau Group west of this fault (Fig. 1). The basal facies of the Otunui Formation are heterolithic, commonly characterised by an onlap shellbed known as the Mangarara Formation (Henderson \& Ongley 1923). At Awakino Heads this unit corresponds to a gritty, glauconitic, calcareous, redeposited sandstone (King et al. 1993). The Otunui Formation is $100-200 \mathrm{~m}$ thick and comprises crudely bedded silty fine sandstone and sandy siltstone, with occasional conglomeratic channels. The Otunui Formation passes conformably upwards into the Mount Messenger Formation, which comprises a slightly calcareous siltstone containing very well sorted massive micaceous sandstone beds (sandy debris flow deposits). The transition to Mount Messenger Formation reflects rapid midWaiauan to lower Tongaporutuan subsidence of the basin to bathyal depths.

The Whangamomona Group comprises an asymmetric transgressive-regressive sequence. Soon after bathyal conditions were achieved in the King Country Basin (upper Waiauan to lower Tongaporutuan) the depositional sequence became regressive with the aggradation of bottomsets (including basin-floor to lower slope fan deposits) and the northward progradation of slope (Urenui and Kiore 

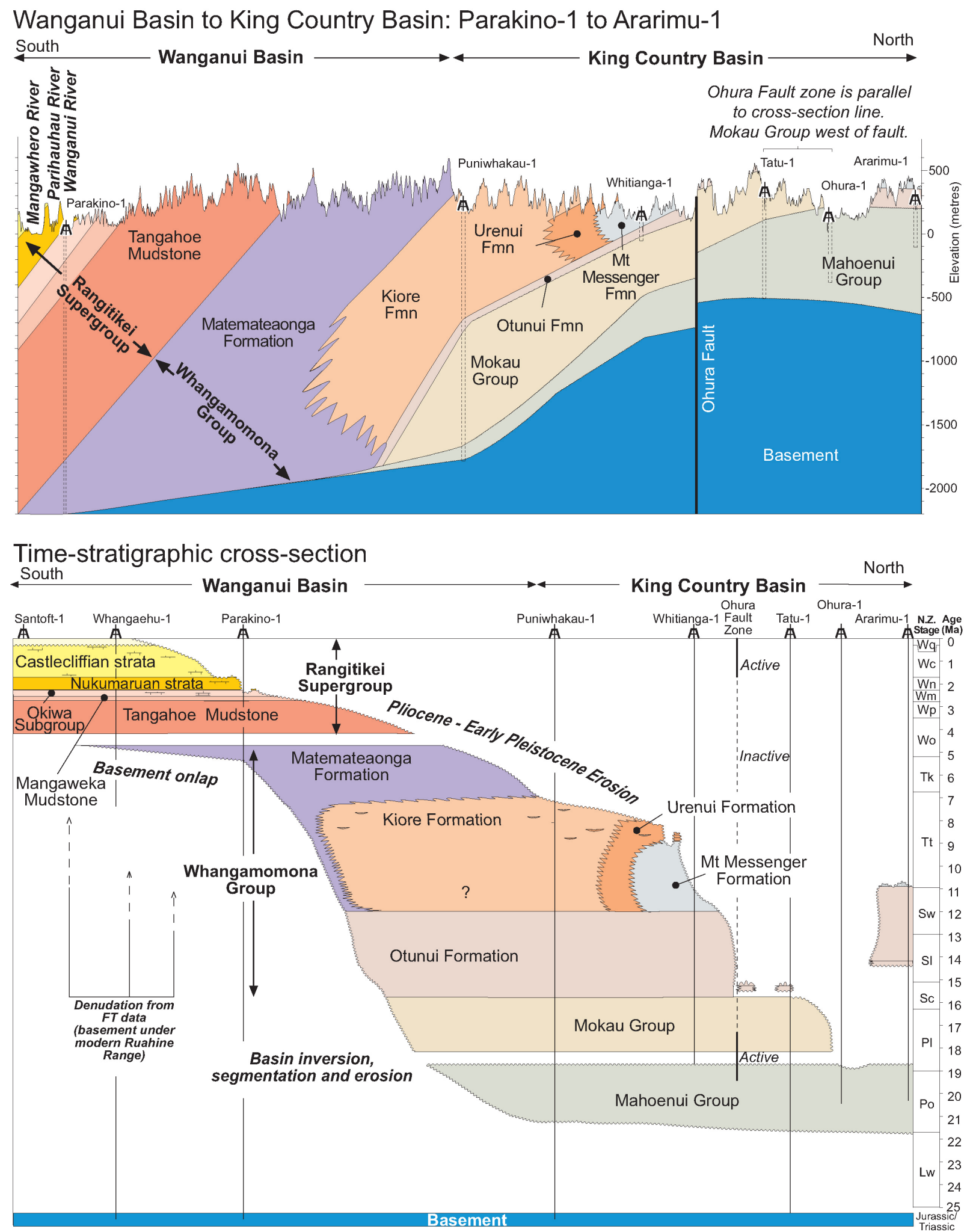

Fig. 6 Wanganui Basin to King Country Basin (Parakino-1 to Ararimu-1) stratigraphic panel built up from well-to-well correlations, and related time-stratigraphic cross-section. The timing of denudation of basement underlying the present Ruahine Range, determined from apatite fission track analysis, is also shown.

Formations) and shelf (Matemateaonga Formation, upper Tongaporutuan to lower Opoitian) deposits. Concurrently, the regressive units, and notably the Matemateaonga Formation, onlapped basement to the south. This geometry required there to be a persistent increase in sediment flux delivered to the continental margin, particularly from c. 10 m.y. ago, after which most of the thickness of the megasequence accumulated. 
Wanganui Basin to Taranaki Basin: Santoft-1A to Tuhua-1

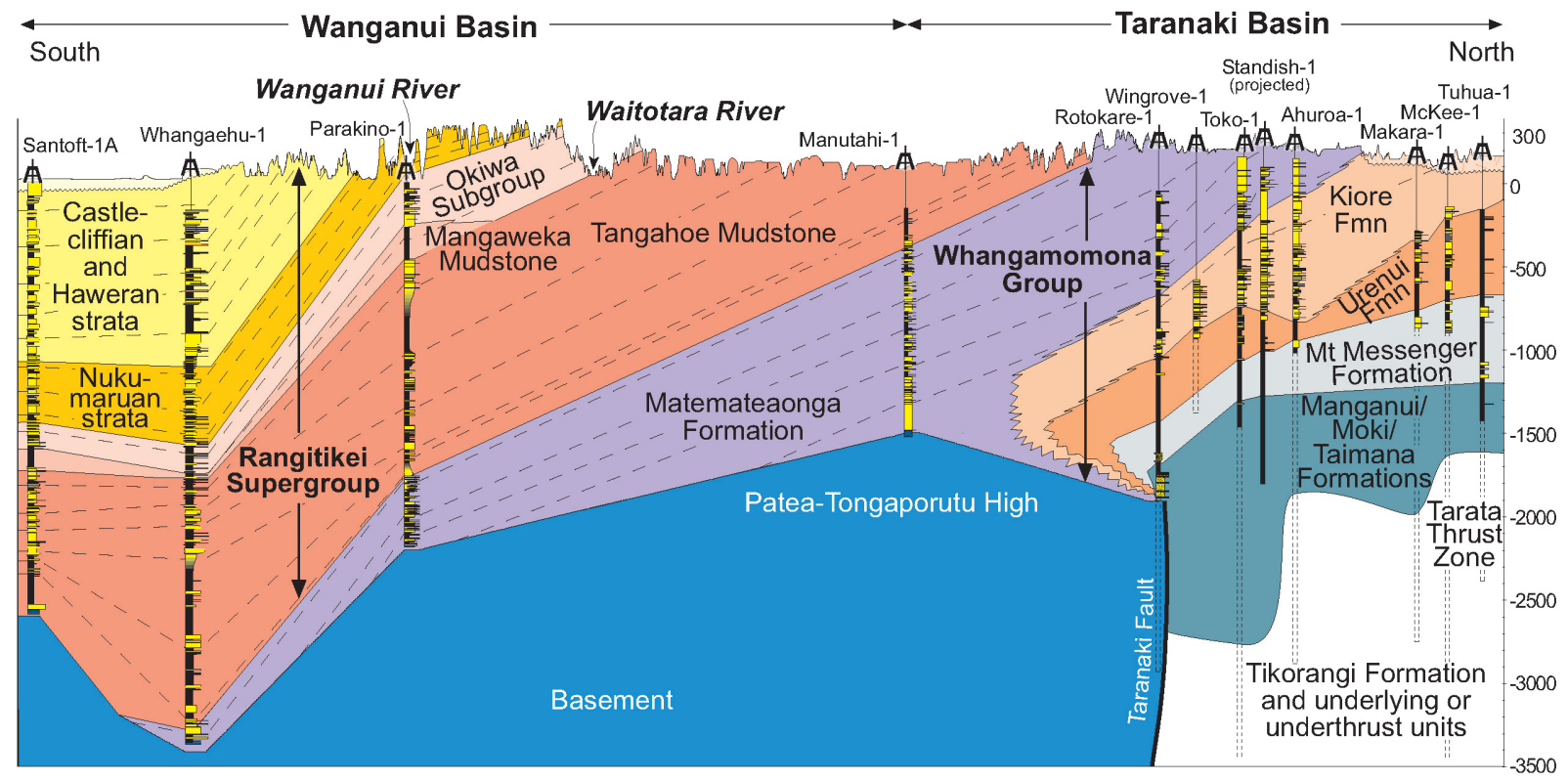

\section{Time-stratigraphic cross-section}

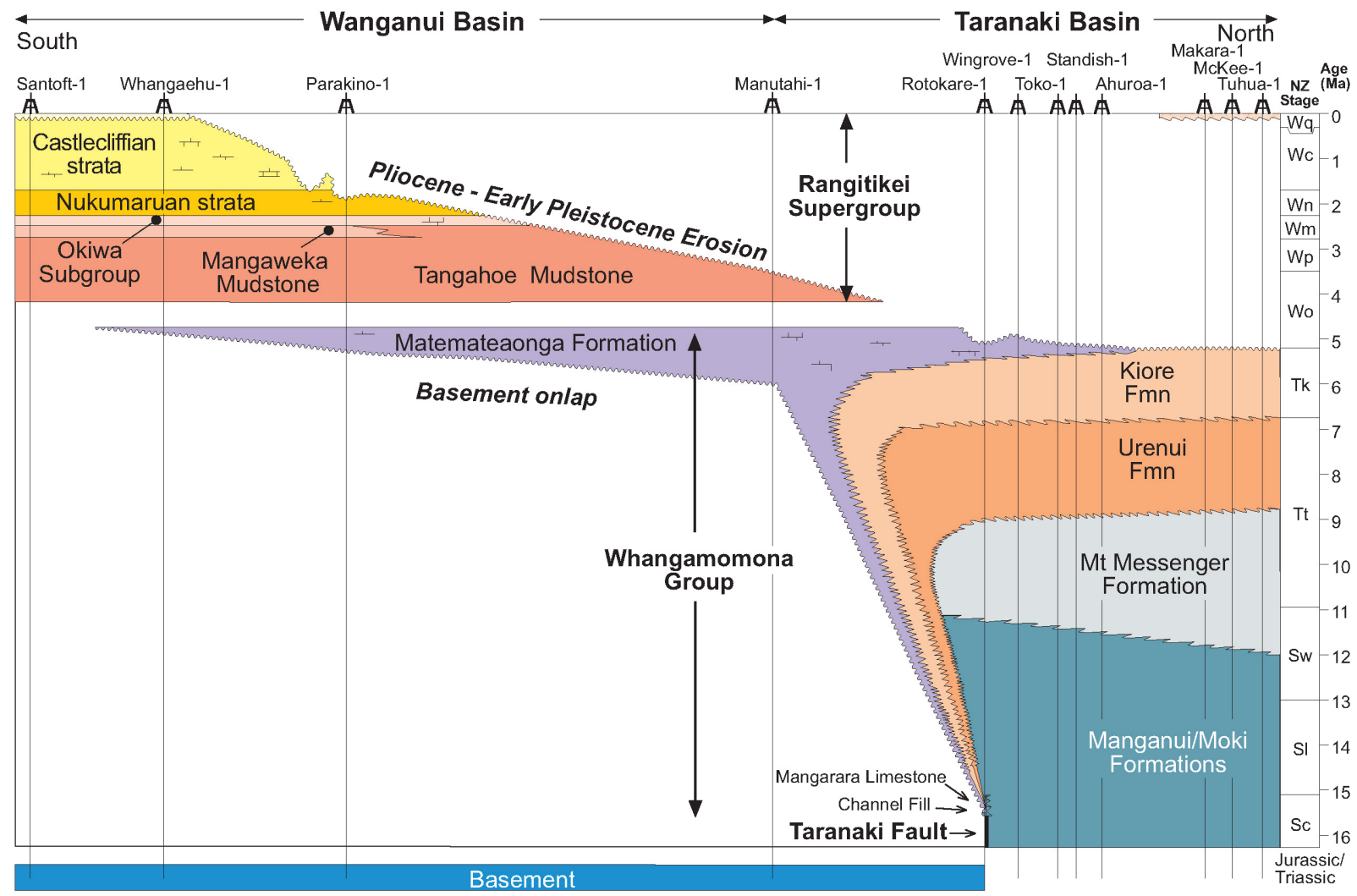

Fig. 7 Wanganui Basin to Taranaki Basin (Santoft-1A to Tuhua-1) stratigraphic panel built up from well-to-well correlations, and related time-stratigraphic cross-section.

The last megasequence comprises the upper Opoitian to upper Castlecliffian Rangitikei Supergroup. In the northern parts of Wanganui Basin, the Tangahoe Mudstone is the basal unit of the Rangitikei Sequence and has also a major flooding surface at its base. It is marked by a $20-30 \mathrm{~cm}$ thick condensed horizon of glauconitic mudstone, which lies a few metres above inner shelf deposits (Hayton 1998). Within the condensed horizon, the paleobathymetry changed from neritic to upper bathyal water depths, and the condensed unit represents some $600000 \mathrm{yr}$ of time across 
the lower-upper Opoitian boundary (Hayton 1998). This is followed upwards, within a few tens of metres, by packets of redeposited sandstone beds that accumulated in broad submarine channels on a continental slope. The upper bathyal deposits (slope-sets) shallow upwards into shelf deposits as a result of shelf and slope progradation during the Waipipian. Mangapanian and younger units make up aggradational shelf deposits (topsets) (e.g., Fleming 1953; Beu \& Edwards 1984; Kamp \& Turner 1990; Abbott \& Carter 1994; Naish \& Kamp 1995, 1997; McIntyre \& Kamp 1998; Kamp \& McIntyre 1998; McIntyre 2001).

\section{Wanganui Basin to eastern Taranaki Basin: Santoft-1A to Tuhua-1 transect}

The cross-section from Santoft-1A to Tuhua-1 starts near the modern depocentre of Wanganui Basin, passes north to Parakino-1 in the Whanganui River valley, east across the Patea-Tongaporutu High to Manutahi-1, north along the eastern margin of Taranaki Basin, and crosses the Taranaki Fault between Rotokare-1 and Wingrove-1 (Fig. 7). It shows the consistent and shallow south-southwesterly dip of the beds irrespective of the basin containing them. The steeper dip of the beds between Parakino-1 and Whangaehu-1 reflects the marked subsidence in Wanganui Basin associated with deposition of the Tangahoe Mudstone.

Figure 7 also shows the chronostratigraphic distribution of the units along the cross-section line. The striking feature is the southward onlap on to basement of the middle Miocene-Pleistocene sedimentary succession, also evident in Fig. 6. This onlap followed the end of substantial displacement on the Taranaki Fault in the peninsula area. The rate of onlap increased markedly during the latest Miocene and earliest Pliocene. The southward onlap implies a northfacing paleoslope. This pattern was clearly reversed after deposition of the Tangahoe Mudstone, with southward tilting involving both the basement and cover succession, and occurring without much differential movement on the Taranaki Fault.

In the Santoft-1A to Tuhua-1 cross-section, the base of the middle-late Miocene Whangamomona Group/Sequence is placed at the base of a limestone succession lying unconformably on basement near the base of Rotokare-1. This limestone has a Clifdenian-Lillburnian age and probably corresponds to the Mangarara Formation. It is also known in other places on the Tongaporutu-Herangi High (Uruti-1 and 2). During accumulation of the Mount Messenger, Urenui, and Kiore Formations there must have been a very narrow shelf along the cross-section line between Rotokare-1 and Manutahi-1, which widened substantially during accumulation of the Matemateaonga Formation.

\section{Taranaki Peninsula: Cape Egmont-1 to Rotokare-1 transect}

Figure 8 is a cross-section across Taranaki Peninsula. The key feature in this cross-section is identification of a paleoshelfslope break, represented by the transition between the topsets of the Matemateaonga Formation and the upper slope-sets of the Kiore Formation. Mapping of the subsurface distribution of these formations depends critically upon interpretation of their wireline log character. Kamp et al. (2002) have outlined the log signals typical of shelf topsets, based on analysis of data and core available for Manutahi-1. Vonk et al. (2002) have outlined a comparable understanding for upper slope- sets based on analysis of wireline data in Kiore Formation from Rotokare-1. The paleoshelf-slope break was strongly aggradational and weakly progradational to the west between Rotokare-1 (23 shelf sequences present, including outcrop above the well site) and Kapuni Deep-1 (2 shelf sequences). The position of the shelf edge was evidently influenced by the Patea-Tongaporutu High and the Tarata Thrust Zone. During the late Miocene and early Pliocene, the main depositional fairway lay to the east of the Patea-Tongaporutu High and was governed by differential subsidence in the axis of the Wanganui to King Country Basins. Consequently, through the latest Miocene (Kapitean) and early Pliocene (lower Opoitian) there was a west-facing slope west of Rotokare-1 and Cardiff-1 (Fig. 8). Farther to the west in Cape Egmont-1, Burgess-1, and Tipoka-1 the Urenui Formation contains lower slope/basin-floor redeposited sandstone beds akin to the fan deposits in the lower part of the Mount Messenger Formation exposed in the North Taranaki coastal section (King et al. 1993).

Figure 8 shows that a very strong distinction occurs between the Tangahoe Mudstone and the MatemateaongaKiore Formations beneath Taranaki Peninsula. This boundary corresponds to a fining of texture and the occurrence in the base of the Tangahoe Mudstone of distinctive redeposited sandstone beds. Despite the occurrence of a slope to basinfloor environment beneath the peninsula during the early Pliocene, this area was still influenced by the Tangahoe tectonic pull-down that was marked across Wanganui Basin at this time. A major effect of the pull-down was that it led to an interval of terrigenous sediment starvation over the northern parts of Wanganui Basin and northern Taranaki Basin (Hansen \& Kamp 2004). The bottomsets and slope-sets of the Tangahoe Mudstone pass upwards into shelf deposits of the Whenuakura Subgroup, which are well exposed in the coastal section south of Hawera, immediately west and east of the Patea-Tongaporutu High (Fleming 1953; Whitten 1973).

In their basin synthesis, King \& Thrasher (1996) placed a group boundary (Wai-iti to Rotokare) at the base of the Matemateaonga Formation, considering this to be widely unconformable in the vicinity of the Taranaki Peninsula. Though we concur that this boundary is unconformable in the Toru Trough, north from Tahi-1 to the Kapuni Field (Fig. 8), this is not the case north and east of Kapuni in Taranaki Peninsula, or in northern Wanganui Basin and eastern Taranaki Peninsula. Consequently, we deliberately group the Matemateaonga Formation with the underlying formations in the Whangamomona Group/Sequence, and do not accept the argument for placing a group boundary (Waiiti to Rotokare) at the base of the Matemateaonga Formation, as proposed in King \& Thrasher (1996). An additional complication in some earlier work has been miscorrelation of shelfal Matemateaonga Formation in eastern Taranaki Peninsula with younger shelfal Whenuakura Subgroup deposits beneath the western parts of Taranaki Peninsula. The Whenuakura Subgroup represents aggradation of topsets of the Rangitikei Sequence in the Central Graben and Toru Trough of Taranaki Basin and in Wanganui Basin following progradation of the related shelf-slope break into the Northern Graben and on to the Western Stable Platform (Hansen \& Kamp 2004). The erosional truncation of the Whangamomona and Rangitikei Sequences over the whole of Taranaki Peninsula is part of the wider doming and erosion of central North Island (Fig. 4). 


\section{Taranaki Peninsula: Cape Egmont-1 to Rotokare-1}

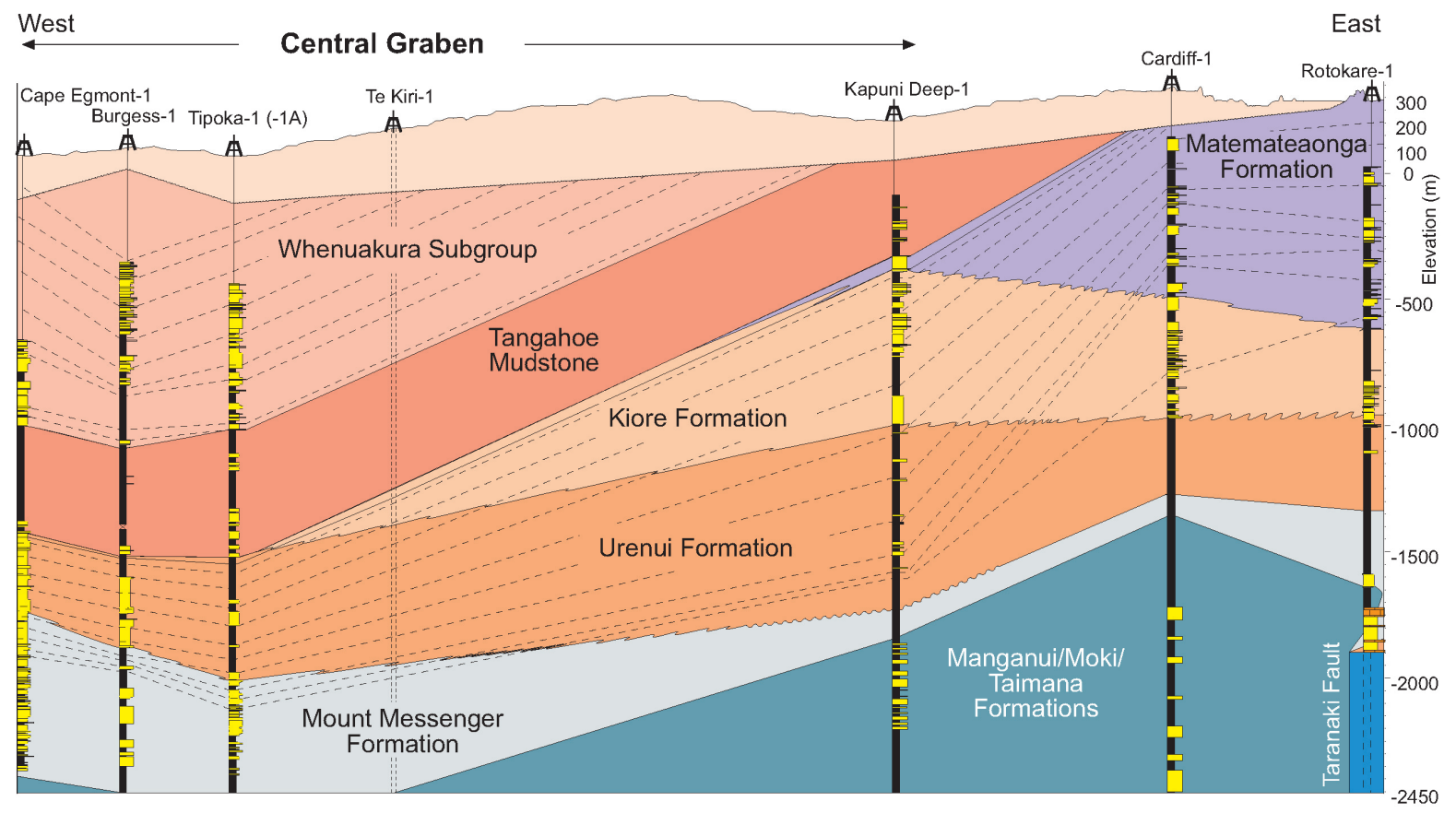

\section{Time-stratigraphic cross-section (extended to Manutahi-1)}

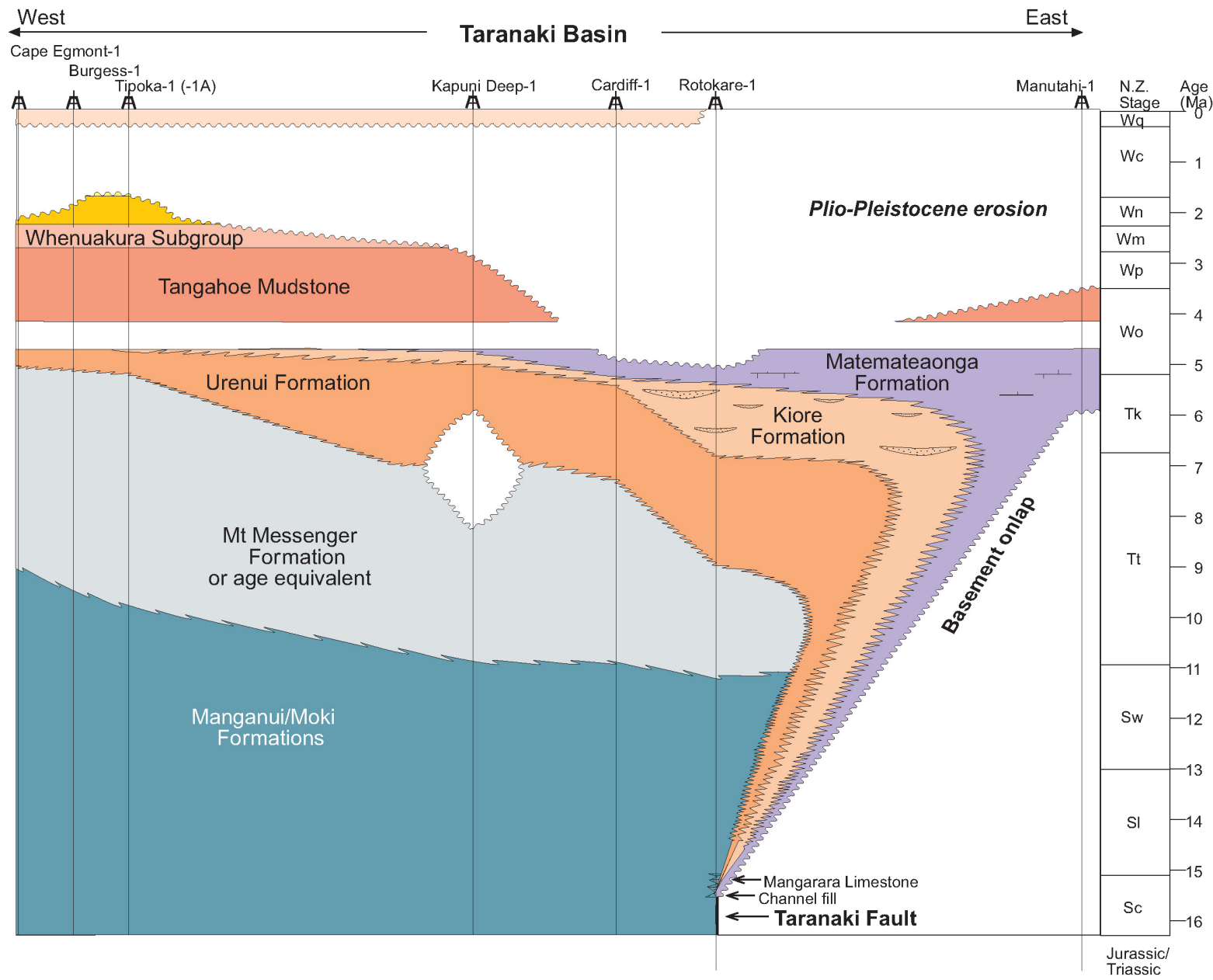

Fig. 8 Taranaki Peninsula (Cape Egmont-1 to Rotokare-1) stratigraphic panel built up from well-to-well correlations, and related timestratigraphic cross-section (extended to Manutahi-1). 


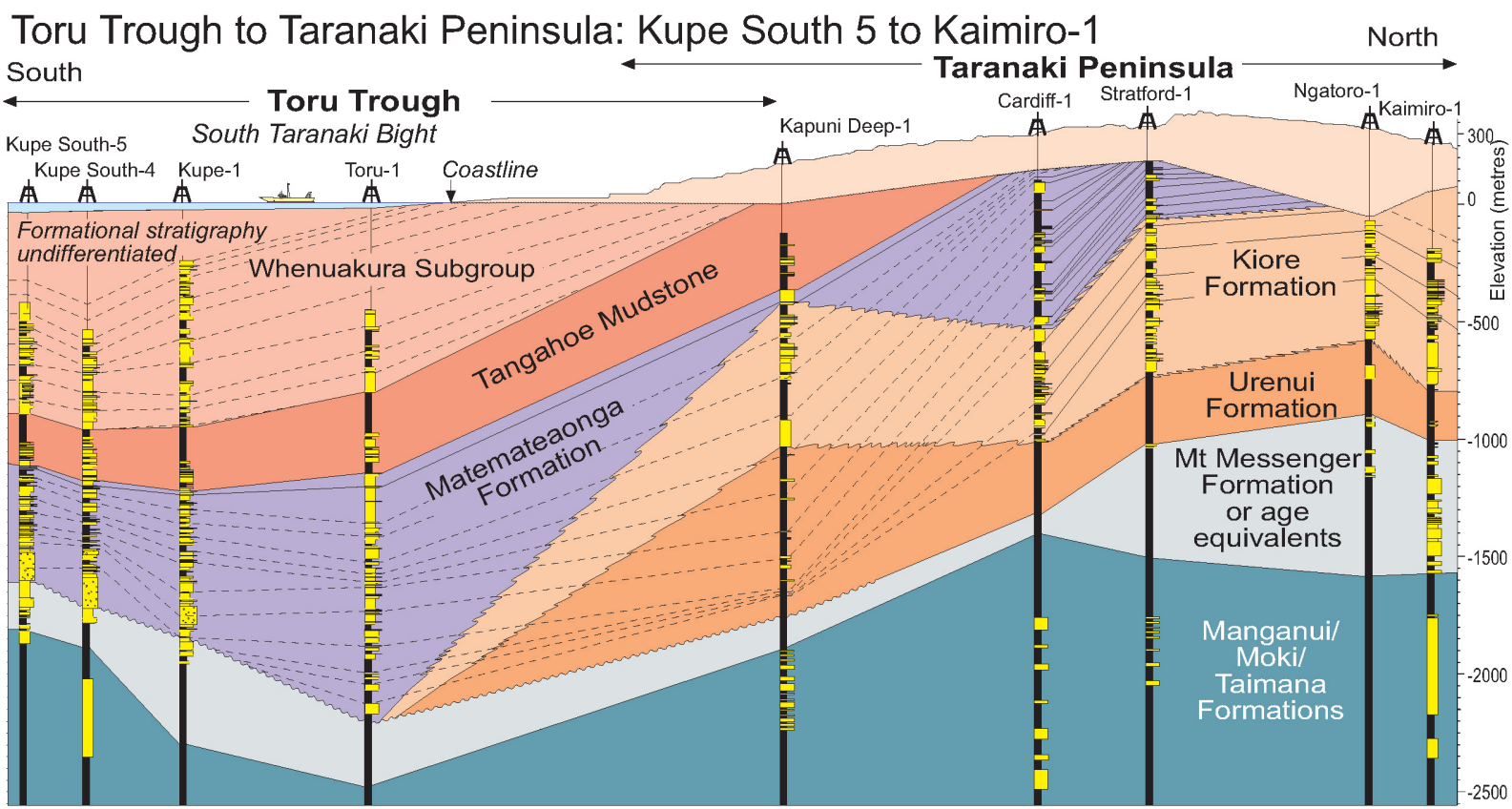

\section{Time-stratigraphic cross-section}

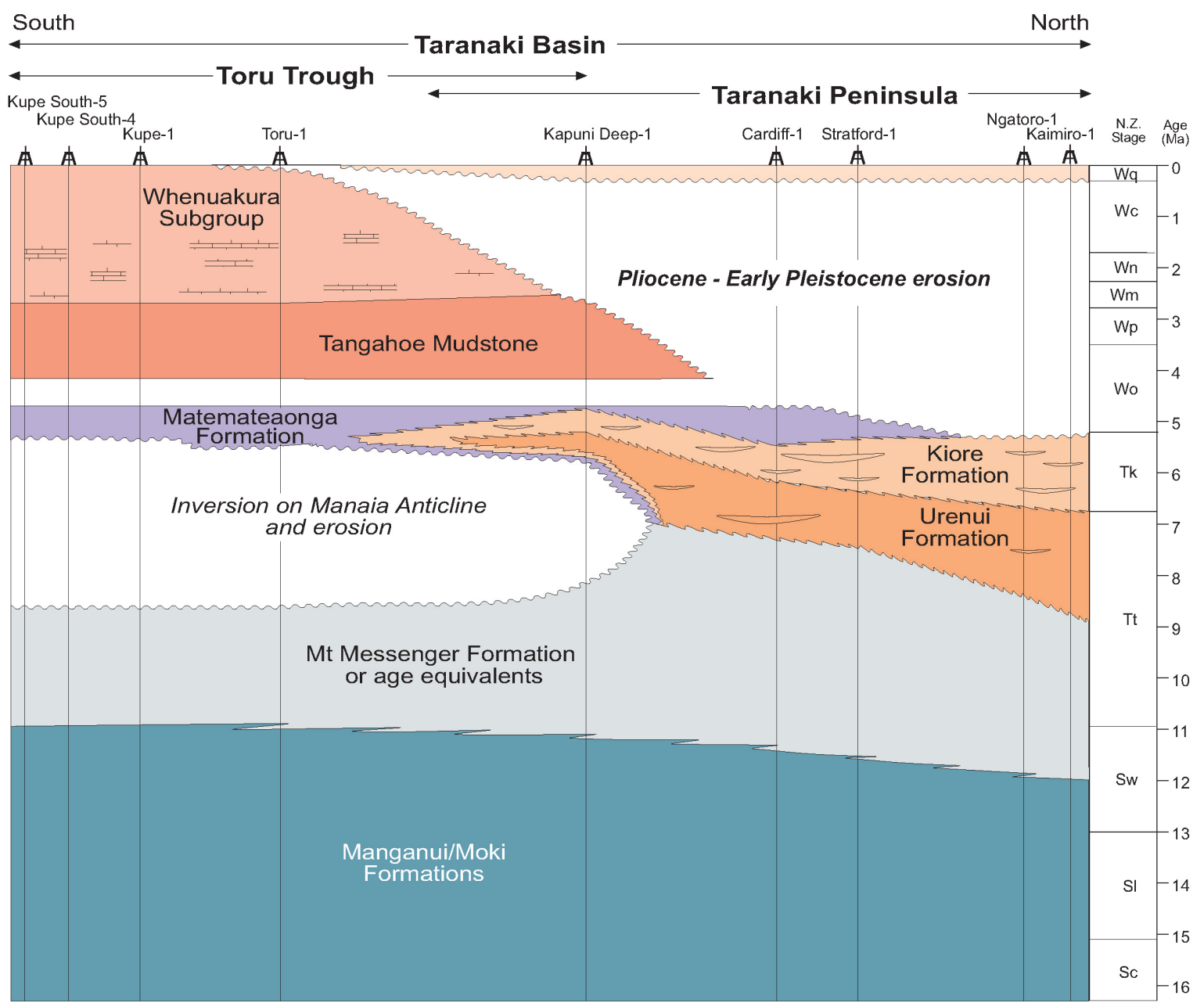

Fig. 9 Toru Trough to Taranaki Peninsula (Kupe South-5 to Kaimiro-1) stratigraphic panel built up from well-to-well correlations, and related time-stratigraphic cross-section. 
Fig. 10 Block diagram showing schematically the occurrence of two continental margin wedges representing the Whangamomona and Rangitikei Sequences, each having prograded northward through central-western North Island during the late Neogene. North is to the right.

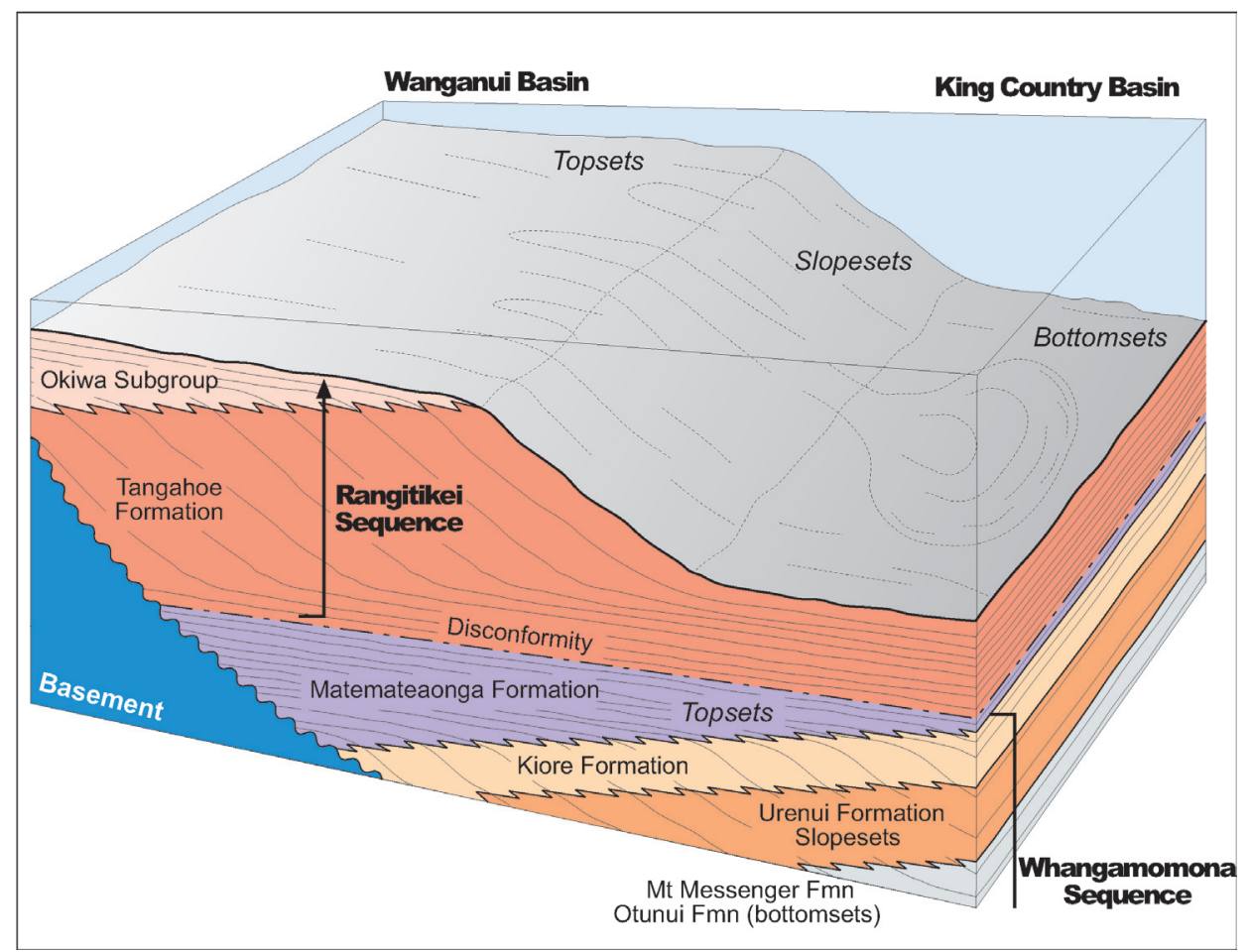

\section{Toru Trough to Taranaki Peninsula: Kupe South-5 to Kaimiro-1 transect}

Figure 9 illustrates a south-north well correlation through Toru Trough into central Taranaki Peninsula. It shows the late Miocene unconformity at the base of the Matemateaonga and Urenui Formations beneath the Toru Trough, reaching as far north as the Manaia Anticline in the Kapuni Field. Facies transitions between the shelfal Matemateaonga Formation and the Kiore and Urenui Formations reflect the line of the cross-section in relation to the former shelf-slope break, with Kapuni Deep-1 lying mostly west of this break, except for accumulation of the youngest two shelf sequences of the Matemateaonga Formation.

The other major feature evident in the cross-section is the dip on the Tangahoe Mudstone to Whenuakura Subgroup deposits and how this dip decreases between Kupe-1 and Kupe South-4. This illustrates the extent of the late tilting that affected the three basins, as described above. It also maps out the extent of the influence of the tectonic pull-down that occurred at the base of the Tangahoe Mudstone and formed the main Wanganui depocentre.

\section{TWO PHASES OF NEOGENE CONTINENTAL MARGIN PROGRADATION}

Figure 10 is a block diagram that shows schematically the depositional and stratigraphic architecture of the two 2nd order sequences comprising the middle Miocene-Pleistocene sedimentary succession in the Wanganui, King Country, and Taranaki Basins. Both the Whangamomona and Rangitikei Sequences formed as northward-prograding continental margin wedges, and had similar topset, slope-set, and bottomset stratal architecture. Unusually, the onlap margin of the Whangamomona Sequence is the preserved component, the deeper water, more oceanward part of the sequence having been uplifted and truncated by erosion in the King Country region.

The Whangamomona Sequence can be mapped along the eastern margin of Taranaki Basin, upon and to the west of the Tongaporutu-Herangi High, part of it being exposed in the northern Taranaki coastal section (Mount Messenger and Urenui Formations) (King et al. 1994; Browne \& Slatt 2002). The Kiore and Matemateaonga Formations crop out to the south in the hill country of eastern Taranaki Peninsula (Vonk et al. 2002).

The Whangamomona Sequence accumulated mainly in the Wanganui and King Country Basins, which reflected the main sedimentary fairway and depositional axis, but the sequence also extended into eastern parts of Taranaki Basin, as outlined above. Correlative beds of the Whangamomona Sequence in Taranaki Basin (Manganui Formation) accumulated in bathyal environments and will be identified on the basis of age. The continental margin comprising the Rangitikei Sequence advanced northward on two fronts, one directly northward from the Southern Alps source through Wanganui Basin and into southern parts of the King Country Basin, while the other was directed west of the Patea-Tongaporutu High through the Toru Trough and into the Central and Northern Grabens of Taranaki Basin and ultimately on to the Western Stable Platform (Hansen \& Kamp 2002, 2004). This sequence forms the thick and extensive deposits underlying the modern shelf and slope in the offshore parts of Taranaki Basin, where it is known as the Giant Foresets Formation. The equivalent sediments have been uplifted and totally removed from the King Country Basin and erosionally truncated in the northern parts of Wanganui Basin and over the Taranaki Peninsula. The Pliocene-Pleistocene erosion of the Whangamomona, Mokau, and Mahoenui Groups in the King Country Basin will have contributed to the source of the sediments making up the Giant Foresets Formation. 


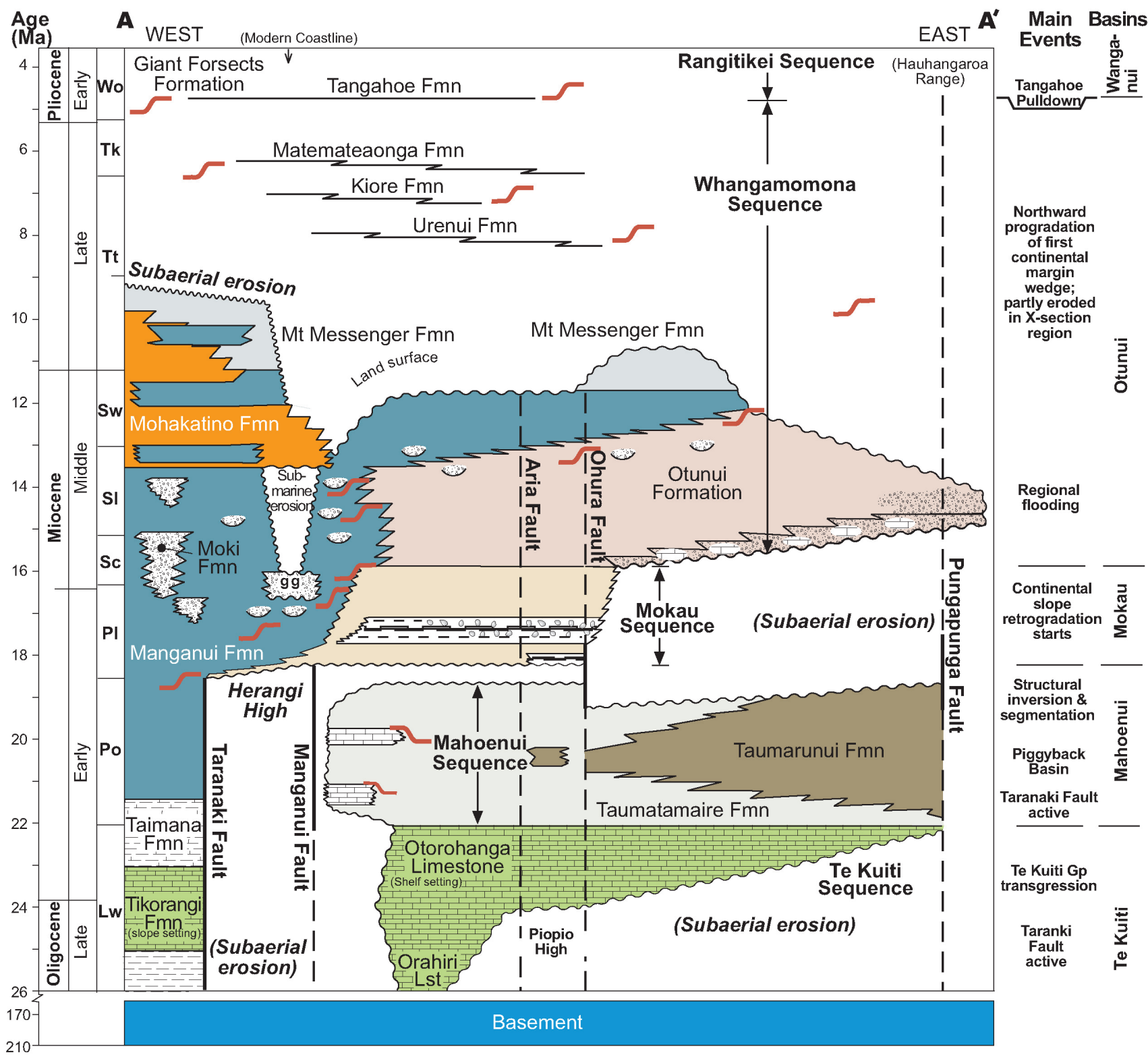

Fig. 11 Chronostratigraphic panel representing the relationship between formations and 2nd order sequences of Cenozoic age cropping out in a cross-section between Awakino Heads in eastern Taranaki Basin and Waitui Saddle on the Hauhungaroa Range along the eastern margin of King Country Basin (line of section A-A' on Fig. 1). The Te Kuiti Sequence represents foundering of the New Zealand platform. The Mahoenui Sequence accumulated in a piggyback basin in response to overthrusting on the Taranaki Fault as the Australia-Pacific plate boundary formed as a through-going transform linked to the Hikurangi Trough offshore eastern North Island. Note the Otaian migration of the shelf-slope break (shown in red symbols) on to the Herangi High from the basins to the west and east. The Altonian Mokau Sequence accumulated in a depression to the west of Ohura Fault Zone and a short distance to the east of the plate boundary to the southeast. Regional flooding occurred during the middle Miocene, possibly in response to emplacement of the subducted slab beneath the King Country Basin (Kamp 1999). At this time the Herangi High disappeared and the shelf-slope break retrograded markedly to the east and south. The Whangamomona Sequence represents the infilling of the King Country Basin, the sediments sourced from the Southern Alps. The lower part of the Rangitikei Sequence is projected northwards onto the cross-section, but it is unclear if the beds extended as far north as the cross-section line. "g" represents occurrence of glauconite. Depocentres within the King Country and Wanganui Basins are noted on the right.

\section{STRATIGRAPHIC ARCHITECTURE ACROSS THE BOUNDARY BETWEEN TARANAKI AND KING COUNTRY BASINS}

In the vicinity of eastern Taranaki Peninsula and Wanganui Basin the major stratigraphic units, as described above, accumulated across the boundaries between all three basins (Fig. 1, 2), reflecting the contemporary broad crustal downwarping and associated sedimentation. Farther to the north where these units have been eroded, the stratigraphic and structural relationships between eastern Taranaki Basin and King Country Basin are much less clear, but are of particular interest as they relate to the timing of basement overthrusting on the Taranaki Fault, movement on other faults, and the change from early Miocene crustal shortening to middle Miocene broad crustal downwarping. Figure 11 is a 
chronostratigraphic panel drawn for a cross-section between Awakino Heads in eastern Taranaki Basin and Waitui Saddle on the Hauhungaroa Range along the eastern margin of King Country Basin. This panel is based on various sources including Happy (1971), Cochrane (1988), King et al. (1993), Nelson et al. (1994), Wilson (1994), King \& Thrasher (1996), Vonk (1999), Vonk et al. (2002), Cartwright (2003), Evans (2003), and our unpublished work. In this section we outline the late Oligocene through middle Miocene stratigraphic and structural development of this eastern Taranaki to King Country margin and its implications.

During most of the Oligocene a structural high (Herangi High) persisted as a semi-continuous paleogeographic feature from south of Awakino to Port Waikato (Nelson 1978). By the late Oligocene this high was inundated north of Raglan Harbour, with accumulation over the top of it of outer shelf Carter Siltstone (Waterhouse \& White 1994). The area around Awakino had a different late Oligocene history. Nelson et al. (1994) have described a distinctive Te Kuiti Group succession at Awakino Tunnel on the eastern side of the Herangi Range where it is generally thick $(300 \mathrm{~m})$, has strong dips $\left(40-30^{\circ}\right)$, exhibits an up-section decrease in the amount of dip, and the capping Orahiri Limestone includes several thick (up to $3 \mathrm{~m}$ ) mass-emplaced units containing a variety of $1-10 \mathrm{~cm}$ sized lithoclasts of older Te Kuiti Group rocks. Petrographic and oxygen and carbon stable isotope data of the lithoclasts suggest that the source deposits were cemented at relatively shallow subsurface burial depths (100-500 m) before being uplifted and eroded. The source for the lithoclasts was probably a lower Whaingaroan sub-basin within Herangi High between Awakino Tunnel and Taranaki Fault. Inversion of this depocentre was accompanied by subtle syn-sedimentary eastward tilting of the Te Kuiti Group strata already deposited on the eastern flank of the Herangi High, contributing to the mass-emplacement of the lithoclast beds and the variable dips evident at Awakino Tunnel. A complementary late Oligocene to earliest Miocene succession on the western flank of Herangi High is represented by the coarse bioclastic phases of the Tikorangi Formation, which were redeposited off a narrow shelf and into a foredeep in the vicinity of the Waihapa-Ngare oil field in Taranaki Peninsula (Hood et al. 2003a,b). Inversion of a depocentre and tilting of the southern part of the high began during the upper Whaingaroan around $30 \mathrm{Ma}$, concomitant with the onset of rapid subsidence along eastern Taranaki Basin, and continued through to the end of the Waitakian Stage (22 Ma, earliest Miocene), when erosion expanded on to the shelf at Awakino Tunnel, stripping out the Otorohanga Limestone in places.

In eastern Taranaki Basin, the latest Oligocene (lower Waitakian) Tikorangi Formation is offset by the Taranaki Fault (Fig. 11), which has its present reverse character in this region as a result of overthrusting of basement into the eastern margin of Taranaki Basin (e.g., King \& Thrasher 1996). The oldest sediments overlying the overthrust basement block are upper Otaian, and more regionally Altonian in age (King $\&$ Thrasher 1996). This brackets the emplacement of the overthrust basement into Taranaki Basin as lying between 23.8 (mid Waitakian; Oligocene/Miocene boundary) and 19.0 Ma (Otaian/Altonian Stage boundary). Taranaki Fault as a pre-existing structure appears to have accommodated part of the compressive regional strain that developed across North Island at that time associated with the development of the Australia-Pacific plate boundary to the east (e.g., Kamp 1986).
On the southeastern flank of Herangi Range near Awakino Tunnel, the Te Kuiti Group is onlapped and overlapped on to basement by early Miocene siliciclastic mudstone and sandstone of the Mahoenui and Mokau Groups, respectively (Fig. 11). The Mahoenui Group is Otaian in age (22-19 Ma) and throughout the King Country region is either a bathyal massive mudstone facies (Taumatamaire Formation) or a flysch facies (Taumarunui Formation). The accumulation of this group and the dramatic change from carbonate to siliciclastic deposits reflects, sedimentologically, uplift and erosion in response to formation of the plate boundary. The regional thicknesses of this mudstone, stratigraphic thicknesses commonly exceeding 1000 m (Topping 1978), cannot be explained by erosion of the Herangi High alone, and the main source probably lay closer to the plate boundary zone to the east.

Near Awakino Tunnel, mapping shows that the Taumatamaire Formation clearly onlaps an unconformity cut across the Te Kuiti Group, which it oversteps to onlap basement (Cochrane 1988). The identification of onlap is facilitated by the occurrence of at least two limestone units (Awakino Limestone Member; Black Creek Limestone Member), which together with thin calc-flysch beds and other subtle lithological variations, identify sufficient bedding within Taumatamaire Formation to establish (1) a pattern and timing of marked syn-sedimentary tilting of the basin margin, and (2) a progradational shelf-slope depositional geometry within the Mahoenui Group north of Awakino Tunnel. We interpret the absence of Otorohanga Limestone at Awakino Tunnel as due to subsequent erosion when the basin margin lay a short distance to the east (we note the presence of Otorohanga Limestone at Rauroa Station and Bexley Station along-strike to the north and south, respectively). The basin margin then subsided differentially during accumulation of Taumatamaire Formation, as indicated by the fanning of dips from 20 to $5^{\circ}$ (Cochrane 1988). The hinge line about which the underlying basement block rotated cannot have been located more than a few hundred metres to a kilometre to the west of the eroded onlap margin where the formation thickness projects to zero. The Manganui Fault (Campbell \& Raine 1989) lies $3 \mathrm{~km}$ to the west of the eroded onlap margin and has the appropriate strike to have acted as the structure controlling the rotation of the block carrying the differentially tilted Taumatamaire Formation. We infer that the Manganui Fault was a high-angle reverse fault at this time, upthrown to the east, with c. $1000 \mathrm{~m}$ of displacement.

As the Taumatamaire Formation beds onlapping the Te Kuiti Group are very fine grained, and the expected neritic facies are very thin, we infer that the initial reverse movement on the Manganui Fault was rapid, perhaps quickly developing some hundreds of metres of topography as a narrow ridge. Reverse faulting and uplift evidently continued through the Otaian (22-19 Ma). Concurrent with the tilting, the Taumatamaire Formation beds developed an eastwarddirected progradational shelf-slope depositional geometry. This is evident from the greater extent of the Black Creek Limestone compared with the Awakino Limestone (Cochrane 1988). In Fig. 11 we show approximately where the shelfslope break lay at various stages. The narrow shelf and limited progradation through several million years of Taumatamaire Formation accumulation probably reflects the effective bypassing in suspension of the fine-grained sediments sourced from the contemporaneous Herangi High, and the excess accommodation available in the Mahoenui depocentre. 
An unconformable contact between the Taumatamaire Formation and Bexley Sandstone (lowermost formation in the Mokau Group) is marked by the development of metres of relief formed by channel erosion in a subaerial environment. The channels were infilled with conglomerate and well-sorted non-marine to innershelf sandstone facies. The Bexley Sandstone maintains similar lithological character and an unconformable relationship with Mahoenui Group over wide areas in the King Country Basin (Vonk 1999). These features imply a change in the pattern of deformation near the Otaian/Altonian boundary from reverse movement on the Manganui Fault, and probably the Taranaki Fault, to more regional uplift and the inversion of the Mahoenui depocentre in the King Country region, as detailed below.

\section{Late-early Miocene to middle Miocene collapse of eastern Taranaki Basin margin}

The youngest parts of the Mahoenui Group in King Country Basin are late Otaian to possibly earliest Altonian in age (Topping 1978). No regressive deposits are associated with this predominantly bathyal succession, even though its unconformable contact with the overlying Mokau Group and Otunui Formation formed through subaerial erosion. This emphasises the regional nature of an initial uplift phase that seems to have involved inversion of the whole of the Mahoenui depocentre (Fig. 11). Through the late Otaian to early Altonian (20-18 Ma) the King Country region was segmented by reverse movement on the Ohura (e.g., Crosdale 1993) and Pungapunga-Hauhaungaroa Faults (Fig. 2) (Cartwright 2003) into three zones, one between Taranaki and Ohura Faults, where Mokau Group mainly accumulated, another between Ohura and Pungapunga-Hauhaungaroa Faults, where Mahoenui Group was partially eroded, and a third east of Pungapunga Fault where Mahoenui Group was completely eroded (Fig. 11). The magnitude of uplift and erosion driven by crustal shortening clearly increased towards the southeast and in the direction of the contemporary plate boundary zone. The Ohura and Pungapunga Faults are younger in age and have more easterly strikes than Taranaki Fault, which could reflect a changing geometry of the plate boundary zone and a shift to the south in the locus of crustal shortening away from the northern part of Taranaki Fault. Reverse movement probably continued on the Taranaki Peninsula sector of the Taranaki Fault, thereby maintaining the juxtaposition of basement against early-middle Miocene sediments (Fig. 7), and on the Tarata Thrust Zone. Hence, we infer that between the Otaian and Altonian there was an easterly change in the orientation of the stress field, with the result that the compressive strain that had been accommodated partly on the Taranaki and Manganui Faults during the Otaian, shifted southeastward to the Ohura and Pungapunga Faults during the late Otaian to early Altonian.

Mokau Group accumulated during the Altonian to a thickness of c. $260 \mathrm{~m}$ mainly northwest of Ohura Fault (Crosdale 1993; Vonk 1999) (Fig. 11). This group comprises three main units: (1) a $60 \mathrm{~m}$ thick lower transgressive shoreface sandstone (Bexley Sandstone); (2) a $120 \mathrm{~m}$ thick middle unit of coal measures, fluvial conglomerate, and shoreface sandstone (Maryville Coal Measures); and (3) an upper $80 \mathrm{~m}$ thick unit of regressive shoreface to innermost shelf sandstone (Tangarakau Sandstone) (Vonk 1999). Concurrently, to the west of the Herangi High, transgressive shoreface facies (Bexley Sandstone) onlapped the basement east of Taranaki
Fault (Fig. 11). This was followed by the accumulation of Manganui Formation mudstone, initially as a shelfal deposit, but by the upper Altonian as a mid-bathyal succession (King et al. 1993). Moki Formation accumulated as submarine channel and fan deposits on a slope to basin floor west and east of the modern coastline. Hence, a complete coastal plain, shoreface, shelf-slope, basin floor linked depositional system developed across the margin between Taranaki and King Country Basins during the Altonian. This depositional system formed over a narrow belt some $35 \mathrm{~km}$ wide. We show in Fig. 11 the approximate positions of the shelf-slope break during the Altonian and infer that this break migrated slowly inland (retrogressed). The system had a strong aggradational component during the Altonian and a narrow shelf, which will have been controlled by the balance between the rate of subsidence of the underlying basement block and by the rate of sediment flux.

The Altonian interval marked the start of the collapse (marked subsidence) of the Kawhia Harbour to Taranaki Peninsula sector of the eastern margin of Taranaki Basin. This collapse accelerated during the early-middle Miocene leading at the end of the middle Miocene to the development of an upper bathyal environment over the eastern Taranaki Basin margin and the King Country region. During the mid Altonian, reverse displacement on the Ohura and Pungapunga Faults ceased, associated with foundering and flooding of the King Country region, possibly in response to emplacement of the subducted slab of Pacific plate beneath the region (Kamp 1999). The basal stratigraphic unit is the Mangarara Formation, which over most of the King Country is a transgressive shellbed. The Otunui Formation is a 100-200 $\mathrm{m}$ thick sandstone to calcareous sandy siltstone, containing a variety of facies typical of an onlapping shoreline through shelf and upper slope succession, including glauconite-rich units (Gerritsen 1994; Cartwright 2003; Evans 2003). It passes gradationally upwards into massive siltstone facies of the Manganui/Mt Messenger Formation. Channelised redeposited sandstone deposits occur within the upper parts of the Otunui Formation and near the transition zone to Manganui/Mt Messenger Formation (Fig. 11). Within 10-50 m of this transition the mass-emplaced sandstone beds (sandy debris flows) become more broadly channelised and are inferred to be part of the Mount Messenger Formation; thicker bedded sandstone units analogous to those exposed in the North Taranaki coastal section occur at higher stratigraphic levels in the southern King Country region and indicate that lower slope to basin-floor environments developed there.

Critical new stratigraphic and sedimentological observations have been made in the Awakino-Mohakatino region in middle Miocene outcrop sections. These pertain to the Mangarara Formation and its relationship to the underlying and overlying beds. In this area the Mangarara Formation comprises a Clifdenian (16-15 Ma), variably calcareous (slightly calcareous to limestone composition) glauconitic sandstone, which in all of the western river catchments accumulated as mass-emplaced beds on a continental slope. It is closely associated with thick-bedded, well sorted sandstone beds that accumulated as channelised sandy debris flows, which we assign to Moki Formation, as described from other parts of Taranaki Basin by de Bock (1994) and King \& Thrasher (1996). The mechanism(s) of emplacement and the continental slope environment of deposition of the Mangarara Formation are common to the Moki Formation, which differs only in carbonate content. The Mangarara Formation facies, 
which are rich in Amphistegina and rhodoliths (calcareous red algal balls), were sourced from shorelines to the east in the King Country region (Fig. 11); sandstone facies of the Moki Formation may also have been derived from the same shorelines, where the sandstone had been well sorted by wave action. The sandstone beds of the Moki Formation, encased in background siltstone facies of the Manganui Formation, persist through the middle Miocene section, whereas the Mangarara Formation beds accumulated mainly during the Clifdenian. We attribute this to the smothering of areas of carbonate production by higher accumulation rates of terrigenous sediment as basin subsidence developed. The Moki and Manganui facies in the Awakino-Mohakatino valleys pass gradationally upwards into Mount Messenger Formation (Ferry Sandstone Member), which is identified by the first occurrence of mass-emplaced thick-bedded sandstone beds whose geometry, by contrast with the stratigraphically lower channelised Moki Formation beds, indicates more widespread distribution as basin-floor fans. The Mohakatino Formation comprises richly volcaniclastic sandstone sourced from andesitic volcanoes of middle-late Miocene age in northern Taranaki Basin. This formation occurs onshore but strongly volcaniclastic facies are restricted to coastal sections (Nodder et al. 1990a,b; King et al. 1993). These sediments occur as either airfall units, or dominantly as mass-emplaced beds. We suggest that the latter could only be transported east of Taranaki Fault once the margin had subsided to bathyal basin-floor depths (Fig. 11). Moreover, the restriction of their occurrence to beds in sections in the vicinity of the modern coastline reflects the northwesterly paleoslope of the retrograding continental margin during the late-middle Miocene.

Between c. $18 \mathrm{Ma}$ (upper Altonian) and $12 \mathrm{Ma}$ (upper Waiauan) there was marked subsidence to bathyal (1000 m) basin-floor environments of what had been land at c. 19 Ma along the eastern margin of Taranaki Basin and in the King Country region (Fig. 11). This subsidence, in the absence of an oversupply of sediment, led to southeastward retrogradation of the continental slope that previously (in the Otaian) had been pinned to the Taranaki Fault. At c. $12 \mathrm{Ma}$, when higher rates of uplift and erosion developed in the plate boundary zone, reflected in higher rates of sediment flux, a continental margin wedge comprising Mount Messenger, Urenui, Kiore, and Matemateaonga Formations started to prograde northward into this basin as the progradational part of the Whangamomona Sequence (Fig. 6, 7, 10, 11). There are no indications that any paleogeographic barriers separated the Taranaki Basin from the King Country Basin north of Taranaki Peninsula. There have been suggestions in the past that the unconformity at the base of the Mangarara Formation in the section at Awakino Heads formed through subaerial erosion and may indicate a middle Miocene uplift phase; rather, we regard this unconformity as having formed through submarine canyon erosion on the contemporary slope, which cut out part of the underlying Manganui Formation. We illustrate in Fig. 11 the Altonian-Lillburnian retrogradation of the continental margin and its subsequent (Waiauan to early Opoitian) progradation via red markings representing successive positions of the shelf-slope break.

The late-early through middle Miocene collapse of the eastern Taranaki Basin margin and of the King Country region followed the successive cessation of reverse movement on four main faults, whose earlier movement had acted to thicken the crust. Reverse displacement on the Taranaki and Manganui
Faults stopped at the end of the Otaian (Fig. 11). Reverse movement was then taken up on the Ohura and Pungapunga Faults, but ended by the close of the Altonian. The flooding of the King Country region was not associated with faulting and appears to be part of a broad crustal downwarp driven below from the mantle and probably associated with the emplacement of the subducted slab of Pacific plate (Kamp 1999). Through the later parts of the middle Miocene this downwarp started to affect the basement east of Taranaki Fault in Taranaki Peninsula, leading to onlap of the Whangamomona Sequence (Fig. 11). This marked the end of most movement on the Taranaki Fault in the peninsula sector, although there are indications from our mapping that the paleogeographic effects of the highstanding hanging wall and neighbouring Tarata Thrust Zone still affected sedimentation patterns during late Miocene accumulation of the Matemateaonga Formation. During the early Pliocene the Wanganui Basin subsided rapidly as a southward migration of the mantle-driven crustal downwarp that affected the more northern areas during the middle Miocene.

\section{Fourth, 5th, and 6th order sequences within Whangamomona and Rangitikei Sequences}

Fourth, 5th, and 6th order sequences are considered to be of 400000,100 000, and $41000 \mathrm{yr}$ duration, the latter two being related to Milankovitch orbital parameters, widely considered to have modulated Earth's climatic and sea-level history during the late Cenozoic. The 100000 yr cyclicity characterises the last $900000 \mathrm{yr}$ of Earth history, whereas $41000 \mathrm{yr}$ cyclicity appears to have been the dominant climatic signal during the late Miocene, Pliocene, and early Pleistocene.

Fourth, 5th, and 6th order sequences are evident to various degrees within the Whangamomona and Rangitikei Sequences. These lower orders of cyclicity are reflected in the lithofacies character and stratal geometry of the formations and units occurring within the megasequences. The 4th, 5th, and 6th order sequences are the level at which reservoir geometry and seal properties are determined. Excluding the 5th order Castlecliffian sequences (Turner \& Kamp 1990; Abbott \& Carter 1994), 6th order sequences are most prevalent in upper parts of the Whangamomona and in Rangitikei Sequences. They are well developed in shelf topsets of the Matemateaonga Formation (Kamp et al. 2002; Vonk et al. 2002), the Whenuakura Subgroup, the Okiwa Subgroup (Kamp \& McIntyre 1998), the Paparangi Subgroup (Kamp et al. 1998), and in Nukumaruan strata (Naish \& Kamp 1995, 1997). This arises because of a very characteristic repetitive succession of shellbed-siltstone-sandstone lithofacies, typically of 25-70 m thickness. Sequences with durations of several hundred thousand years, possibly 4th order, are evident in the Matemateaonga Formation in axial parts of Wanganui Basin, and in parts of the Rangitikei Supergroup (e.g., Mangaweka Mudstone). Their origin is considered to relate to tectonically driven pulses of subsidence rather than to climatic or sea-level oscillations.

The identification of 4th, 5th, and 6th order sequences in the slope-sets and bottomsets of the Whangamomona Sequence is more difficult to achieve and to date than for the topsets. King et al. (1994) have described sequences in the Urenui Formation and Mount Messenger Formation in the northern Taranaki coastal section which are probably of 5th order cyclicity. The combination of the inclined depositional surface in slope environments, the more random depositional 
and mass movement processes that occur off the shelf, and the accidental position of outcrop sections and drillhole locations with respect to the depositional lobes, conspire to make it difficult to reconstruct a comprehensive record of higher order sequences in off-shelf settings, and so to establish their periodicity.

\section{CONCLUDING REMARKS AND PALEOGEOGRAPHIC IMPLICATIONS}

King et al. (1999) have synthesised the Cretaceous-Recent sedimentation patterns in New Zealand basins and interpreted them in terms of $1 \mathrm{st}$ and 2 nd order megasequences of tectonic origin. A continent-wide synthesis requires a degree of generalisation and compromise to be made to identify the unifying features, but these are inevitably made at the expense of regional differences. This work has re-examined the Neogene stratigraphic architecture of Wanganui Basin, King Country Basin, and eastern parts of Taranaki Basin, and established that since the early Miocene, four 2 nd order sequences have formed rather than three, including the Mahoenui Group, Mokau Group, Whangamomona Group (new), and Rangitikei Supergroup (new). Their origin relates to the wider evolution of the Australia-Pacific plate boundary zone, and more particularly to the emplacement of the subducted slab of Pacific plate beneath the centralwestern North Island region (Kamp 1999). The number, age, and character of these sequences are therefore unlikely to correlate precisely with 2 nd order sequence development elsewhere in New Zealand, particularly in South Island basins, where the tectonic history was dominated by different plate boundary processes.

The crustal shortening that led to the marked subsidence of King Country Basin as a piggyback basin during the earliest Miocene (Otaian) and accumulation of Mahoenui Group, was expressed as basement overthrusting along the Taranaki Fault, reverse movement on the Manganui Fault, and by a marked transition from carbonate to terrigenous sedimentation. The Herangi High formed a western margin to the Mahoenui depocentre, whereas the eastern extent of the Mahoenui Group is eroded and the depocentre clearly extended much farther to the east, possibly as far as the East Coast Basin. The muddy sediment was probably distantly sourced, possibly from basement uplifted and eroded in the contemporary plate boundary zone to the east.

Crustal shortening at the end of the Otaian to earliest Altonian lead to inversion of the whole of the Mahoenui depocentre associated with reverse movement on the Ohura and Pungapunga Faults. This may have coincided with continuing reverse movement on the Tarata Thrust Zone in the Taranaki Peninsula region. It was accompanied by subsidence and onlap of Manganui Formation on to the Herangi High, and by the accumulation of shoreface and fluvial sediments and coal measures of the Mokau Group in western parts of King Country Basin. The Mokau Group is transgressive at its base, regressive in its upper parts, and has a gradational upper contact into the Otunui Formation, which suggests that it was not uplifted and eroded. The Mokau Group was sourced chiefly from erosion of Murihiku Terrane basement underlying the Tongaporutu-Herangi High, together with erosion of Waipapa Terrane in central North Island (Vonk 1999). During the Altonian a very narrow continental shelf developed above the Herangi High (Fig. 11).
Regional early-middle Miocene subsidence marks the collapse of the eastern margin of Taranaki Basin. This led to the accumulation in King Country Basin of a distinctive basal onlap facies (Mangarara Formation), followed by the Otunui Formation which accumulated in shelfal to upper bathyal environments. By the upper Waiauan the King Country Basin had subsided to bathyal depths and a continental margin had retrogressed into the basin from the eastern margin of Taranaki Basin. The Otunui Formation clearly overlaps the Ohura and Pungapunga Faults, which ceased reverse movement by the end of the Altonian. The Otunui Formation was probably sourced from basement eroded in central and southern North Island, as suggested by unpublished fission track thermochronological results. The Mount Messenger Formation accumulated mainly during the lower Tongaporutuan and represents the appearance of a high sediment flux sourced chiefly from erosion of Torlesse Terrane and Alpine Schist eroded from the Southern Alps, which started to be eroded from the late-middle Miocene (Kamp \& Tippett 1993). This sediment was fed via northward flowing rivers across basement topography, now buried beneath Wanganui Basin, to cause progradation of the first of two continental margin wedges in King Country, Wanganui, and eastern Taranaki Basins.

The terrigenous sediment supply to King Country Basin, northern parts of Wanganui Basin, and Taranaki Basin was dramatically reduced during the middle Pliocene when the basement underlying Wanganui Basin was tectonically rapidly pulled down, thereby trapping sediment. A second continental margin wedge then prograded north from the southern part of Wanganui Basin, forming the Rangitikei Sequence. This margin had two fronts, one that moved north along the axis of the Wanganui-King Country Basin, and another to the west of the Patea-Tongaporutu High, which prograded north through the Toru Trough and Central Graben into the Northern Graben and westward on to the Western Platform. This prograding wedge makes up the Giant Foresets Formation and underlies the modern shelf and slope west of central-western North Island (Hansen \& Kamp 2004).

During the Pliocene, the andesitic volcanic arc migrated from the northern Taranaki Basin to the Taupo Volcanic Zone, probably as a result of steepening of the subducted slab (Kamp 1984). The emplacement of the mantle wedge beneath central North Island and associated processes caused long wavelength doming of the crust. Associated erosion of weakly consolidated mudstone and sandstone beds of the Mahoenui, Mokau, and Whangamomona Groups in King Country Basin amounted to a maximum of c. $2000 \mathrm{~m}$, but this reduced outwards to the west (eastern Taranaki Basin), south (Wanganui Basin), and east (Hawke's Bay Basin). The erosional truncation of the deeper water part of the Whangamomona Sequence emphasises the magnitude and scale of this crustal doming and erosion.

\section{ACKNOWLEDGMENTS}

We thank Laurence Gaylor for field assistance throughout this project, Paul Haitana (Pipiriki) for guidance in our work up the Whanganui River valley, Geoffrey Cable for lab assistance with bulk density determinations, and Betty-Ann Kamp for cartographic assistance. We thank Peter King, Tim Naish, and Greg Browne for their helpful research interactions with us (particularly PJJK and CSN) over many years on the character and origin of the sequences of central-western North Island basins. We thank the Institute of 
Geological \& Nuclear Sciences Ltd for the provision of bulk density data for mudstone units cropping out over parts of central-western North Island. We acknowledge the Foundation for Research, Science and Technology for research funding (contracts UOW608 and UOWX0301).

\section{REFERENCES}

Abbott, S. T.; Carter, R. M. 1994: The sequence architecture of midPleistocene (c. 1.1-0.4 Ma) cyclothems from New Zealand: facies development during a period of orbital control on sea level cyclicity. In: de Boer, P. L.; Smith, D. G. ed. Orbital forcing and cyclic sequences. Special Publication of the International Association of Sedimentologists 19: 367-394.

Armstrong, P .A.; Allis, R. G.; Funnell, R. H.; Chapman, D. S 1998: Late Neogene exhumation patterns in Taranaki basin (New Zealand): evidence from offset porosity-depth trends Journal of Geophysical Research 103: 30269-30282.

Beu, A. G.; Edwards, A. R. 1984: New Zealand Pleistocene and late-Pliocene glacio-eustatic cycles. Palaeogeography, Palaeoclimatology, Palaeoecology 46: 119-142.

Browne, G. H.; Slatt, R. M. 2002: Outcrop and behind outcrop characterization of a late Miocene slope fan system, Mt. Messenger Formation, New Zealand. American Association of Petroleum Geologists Bulletin 86: 841-862.

Campbell, H. J.; Raine, J. I. 1989: Biostratigraphic evidence for the Manganui Fault, near Awakino, southwest Auckland. Journal of the Royal Society of New Zealand 19: 43-53.

Cartwright, S. J. 2003: Cenozoic geological evolution of the centraleastern King Country Basin, North Island. Unpublished MSc thesis, University of Waikato, Hamilton, New Zealand.

Cochrane, P. R. 1988: The stratigraphy and structure of the early Miocene Mahoenui Group, northern Awakino Gorge: controls on cyclic carbonate-terrigenous sedimentation. Unpublished MSc thesis, University of Waikato, Hamilton, New Zealand.

Crosdale, P. J. 1993: Regression-related coal-bearing sequences in the Neogene of New Zealand: relation to the developing Alpine fault transform. In: Ballance, P. F. ed. South Pacific sedimentary basins. Sedimentary basins of the World 2. Amsterdam, Elsevier. Pp. 279-293.

de Bock, J. F. 1994: Moki Formation, a Miocene reservoir sequence, its facies distribution and source in offshore southern Taranaki Basin. 1994 New Zealand Petroleum Conference Proceedings. The Publicity Unit, Crown Minerals Operations Group, Energy and Resources Division, Ministry of Commerce. Pp. 155-167.

Evans, T. P. H. 2003: Stratigraphy and sedimentology of early to middle Miocene strata, western Taumarunui region, King Country Basin. Unpublished MSc thesis, University of Waikato, Hamilton, New Zealand.

Fleming, C. A. 1953: The geology of Wanganui Subdivision. New Zealand Geological Survey Bulletin 52.362 p.

Franklin, I. A.; Volger, U. W.; Szlavin, J.; Edmond, J. M.; Bieniawski, Z. T. 1979: Suggested methods for determining water content, porosity, density, absorption and related properties and swelling and slake-Durability Index properties. International Journal of Rock Mechanics and Mining Sciences and Geomechanics 16: 141-156.

Gerritsen, S. W. 1994: The regional stratigraphy and sedimentology of the Miocene sequence in the Ohura-Taumarunui region. Unpublished MSc thesis, University of Waikato, Hamilton, New Zealand.

Hansen, R. J.; Kamp, P. J. J. 2002: Evolution of the Giant Foresets Formation, northern Taranaki Basin, New Zealand. 2002 New Zealand Petroleum Conference Proceedings, Auckland, 24-27 February. Wellington, Ministry of Economic Development. Pp. 419-435.
Hansen, R. J.; Kamp, P. J. J. 2004: Late Miocene to early Pliocene stratigraphic record in northern Taranaki Basin: condensed sedimentation ahead of Northern Graben extension and progradation of the modern continental margin. New Zealand Journal of Geology and Geophysics 47: 645-662 (this issue).

Happy, A. J. 1971: Tertiary geology of the Awakino area, North Taranaki. Unpublished MSc thesis, University of Auckland, Auckland, New Zealand.

Hay, R. F. 1967: Sheet 7-Taranaki. Geological map of New Zealand 1:250,000. Wellington, New Zealand. Department of Scientific and Industrial Research.

Hayton, S. H. 1998: Sequence stratigraphic, paleoenvironmental, and chronological analysis of the late Neogene Wanganui River section, Wanganui Basin. Unpublished PhD thesis, University of Waikato, Hamilton, New Zealand.

Henderson, J.; Ongley, M. 1923: The geology of the Mokau Subdivision. New Zealand Geological Survey Bulletin 24.

Hendy, A. J. W.; Kamp, P. J. J. 2004: Late Miocene to early Pliocene biofacies of Wanganui and Taranaki Basins, New Zealand: applications to paleoenvironmental and sequence stratigraphic analysis. New Zealand Journal of Geology and Geophysics 47: 769-785 (this issue).

Hood, S. D.; Nelson, C. S.; Kamp, P. J. J. 2003a: Lithostratigraphy and depositional episodes of the Oligocene carbonate-rich Tikorangi Formation, Taranaki Basin, New Zealand. New Zealand Journal of Geology and Geophysics 46: 363-386.

Hood, S. D.; Nelson, C. S.; Kamp, P. J. J. 2003b: Petrogenesis of diachronous mixed siliciclastic-carbonate megafacies in the cool-water Oligocene Tikorangi Formation, Taranaki Basin, New Zealand. New Zealand Journal of Geology and Geophysics 46: 387-405.

Kamp, P. J. J. 1984: Neogene and Quaternary extent and geometry of the subducted Pacific Plate beneath North Island, New Zealand: implications for Kaikoura tectonics. Tectonophysics 108: 241-266.

Kamp, P. J. J. 1986: The mid-Cenozoic Challenger Rift System of western New Zealand and its implications for the age of Alpine Fault inception. Geological Society of America Bulletin 97: 255-281.

Kamp, P. J. J. 1999: Tracking crustal processes by FT thermochronology in a forearc high (Hikurangi margin, New Zealand) involving Cretaceous subduction termination and mid-Cenozoic subduction initiation. Tectonophysics 307: 313-343.

Kamp, P. J. J.; McIntyre, A. P. 1998: The stratigraphic architecture of late Pliocene (2.8-2.4 Ma) asymmetrical shelf sequences, western Wanganui Basin, New Zealand. Sedimentary Geology 122: 53-67.

Kamp, P. J. J.; Tippett, J. M. 1993: Dynamics of Pacific plate continental crust in the South Island collision zone (New Zealand). Journal of Geophysical Research 98: 1610516118.

Kamp, P. J. J.; Turner, G. 1990: Pleistocene unconformity bounded sequences (Wanganui Basin, New Zealand) correlated with global isotope record. Sedimentary Geology 68: 155-161.

Kamp, P. J. J.; Journeaux, T. D.; Morgans, H. E. G. 1998: Cyclostratigraphy of middle Pliocene mid-shelf to upper slope strata, eastern Wanganui Basin (New Zealand): correlations to the deep sea isotope record. Sedimentary Geology 117: 165-192.

Kamp, P. J. J.; Vonk, A. J.; Bland, K. J. and others 2002: Megasequence architecture of Taranaki-Wanganui-King Country Basins and Neogene progradation of two continental margin wedges across western New Zealand. 2002 New Zealand Petroleum Conference Proceedings, Auckland, 24-27 February. Wellington, Ministry of Economic Development. Pp. 464-481. 
King, P. R.; Thrasher, G. P. 1996: Cretaceous-Cenozoic geology and petroleum systems of the Taranaki Basin, New Zealand. Institute of Geological \& Nuclear Sciences Monograph 13. 243 p.

King, P. R.; Scott, G. H.; Robinson, P. H. 1993: Description, correlation and depositional history of Miocene sediments outcropping along the North Taranaki coast. Institute of Geological \& Nuclear Sciences Monograph 5. 199 p. Lower Hutt, Institute of Geological \& Nuclear Sciences Ltd.

King, P. R.; Browne, G. H.; Slatt, R. M. 1994: Sequence architecture of exposed late Miocene basinfloor fan and channel-levee complexes (Mount Messenger Formation), Taranaki Basin, New Zealand. In: Weimer, P.; Bouma, A. H.; Perkins, B. F. ed. Submarine fans and turbidite systems. Gulf Coast Section, Society of Economic Paleontologists and Mineralogists Foundation, 15th Annual Research Conference. Pp. 172-192.

King, P. R.; Naish, T. R.; Browne, G. H.; Field, B. D.; Edbrooke, S. W. comp. 1999: Cretaceous to Recent sedimentary patterns in New Zealand. Institute of Geological \& Nuclear Sciences Folio Series 1. Lower Hutt, Institute of Geological \& Nuclear Sciences Ltd.

McIntyre, A. P. 2001: Geology of Mangapanian (late Pliocene) strata, Wanganui Basin: lithostratigraphy, paleontology and sequence stratigraphy. Unpublished $\mathrm{PhD}$ thesis, University of Waikato, Hamilton, New Zealand.

McIntyre, A. P.; Kamp, P. J. J. 1998: Late Pliocene (2.8-2.4 Ma) cyclothemic shelf deposits, Parikino, Wanganui Basin, New Zealand: lithostratigraphy and correlation of cycles. New Zealand Journal of Geology and Geophysics 41: 69-84.

Naish, T. R.; Kamp, P. J. J. 1995: Late Pliocene marine cyclothems, Wanganui Basin, New Zealand. New Zealand Journal of Geology and Geophysics 38: 223-243.

Naish, T. R.; Kamp, P. J. J. 1997: Sequence stratigraphy of 6th order (41 k.y.) Pliocene-Pleistocene cyclothems, Wanganui Basin, New Zealand: a case for the regressive systems tract. Geological Society of America Bulletin 109: 978-999.

Nelson, C. S. 1978: Stratigraphy and paleontology of the Te Kuiti Group, Waitomo County, South Auckland, New Zealand. New Zealand Journal of Geology and Geophysics 21: 223-243.

Nelson, C. S.; Hume, T. M. 1977: Relative intensity of tectonic events revealed by the Tertiary sedimentary record in the North Wanganui Basin and adjacent areas, New Zealand. New Zealand Journal of Geology and Geophysics 20: 369-392.

Nelson, C. S.; Kamp, P. J. J.; Young, H. R. 1994: Sedimentology and petrography of mass-emplaced limestone (Orahiri Limestone) on a late Oligocene shelf, western North Island, and tectonic implications for eastern margin development of Taranaki Basin. New Zealand Journal of Geology and Geophysics 37: 269-285.
New Zealand Geological Survey 1972: North Island. Geological map of New Zealand 1: 1000 000. Wellington, New Zealand, Department of Scientific and Industrial Research.

Nodder, S. D.; Nelson, C. S.; Kamp, P. J. J. 1990a: Middle Miocene formational stratigraphy (Mokau-Mohakatino Groups) at Waikawau, northeastern Taranaki Basin margin, New Zealand. New Zealand Journal of Geology and Geophysics 33: 585-598.

Nodder, S. D.; Nelson, C. S.; Kamp, P. J. J. 1990b: Mass-emplaced siliciclastic-volcaniclastic-carbonate sediments in middle Miocene shelf-to-slope environments at Waikawau, northern Taranaki and some implications for Taranaki Basin development. New Zealand Journal of Geology and Geophysics 33: 599-615.

Reilly, W. I. 1965: Gravity map of New Zealand 1:4 000000. Bouger and isostatic anomalies. Wellington, New Zealand, Department of Scientific and Industrial Research.

Topping, R. M. 1978: Foraminifera from the Mahoenui Group, North Wanganui Basin. Unpublished PhD thesis, University of Auckland, Auckland, New Zealand.

Turner, G. M.; Kamp, P. J. J. 1990: Paleomagnetic location of the Jaramillo subchron and Brunhes-Matuyama transition in the Castlecliffian stratotype section, Wanganui Basin, New Zealand. Earth and Planetary Science Letters 100: 42-50.

Vonk, A. J. 1999: Stratigraphic architecture and sedimentology of the early Miocene Mokau Group, North Wanganui Basin, western North Island, New Zealand. Unpublished MSc thesis, University of Waikato, Hamilton, New Zealand.

Vonk, A. J.; Kamp, P. J. J.; Hendy, A. W. 2002: Outcrop to subcrop correlations of late Miocene-Pliocene strata, Taranaki Peninsula. 2002 New Zealand Petroleum Conference Proceedings, Auckland, 24-27 February. Wellington, Ministry of Economic Development. Pp. 234-255.

Waterhouse, B. C.; White, P. J. 1994: Geology of the Raglan-Kawhia area, scale 1:50 000. Institute of Geological \& Nuclear Sciences Geological Map 13. 1 map and booklet 48 p. Lower Hutt, Institute of Geological \& Nuclear Sciences Ltd.

Whitten, R. F. 1973: The Waipipian stratigraphy and paleoecology of the South Taranaki Coast. Unpublished MSc thesis, University of Auckland, Auckland, New Zealand.

Wilson, B. T. 1994: Sedimentology of the Miocene succession (coastal section), eastern Taranaki Basin margin: sequence stratigraphic interpretation. Unpublished MSc thesis, University of Waikato, Hamilton, New Zealand. 